Discussion

Papers

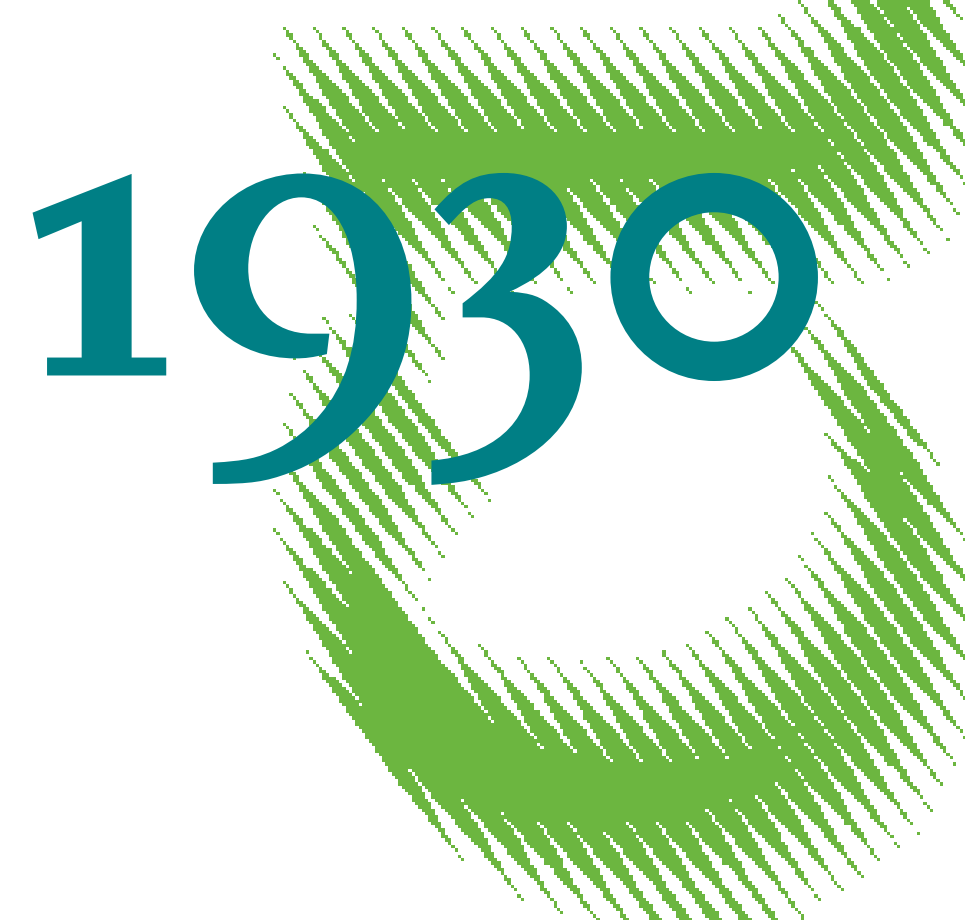

aill

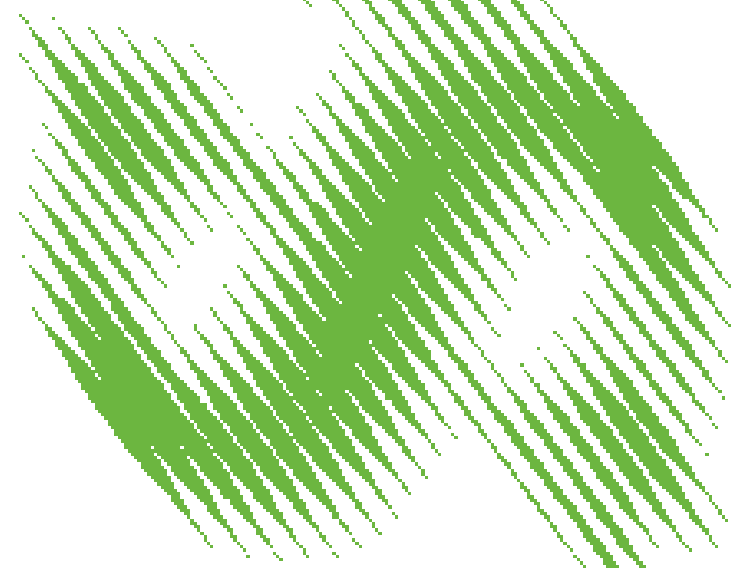

Market Concentration in Europe: Evidence from Antitrust Markets 
Opinions expressed in this paper are those of the author(s) and do not necessarily reflect views of the institute.

IMPRESSUM

(C) DIW Berlin, 2021

DIW Berlin

German Institute for Economic Research

Mohrenstr. 58

10117 Berlin

Tel. +49 (30) $89789-0$

Fax +49 (30) $89789-200$

http://www.diw.de

ISSN electronic edition 1619-4535

Papers can be downloaded free of charge from the DIW Berlin website:

http://www.diw.de/discussionpapers

Discussion Papers of DIW Berlin are indexed in RePEc and SSRN:

http://ideas.repec.org/s/diw/diwwpp.html

http://www.ssrn.com/link/DIW-Berlin-German-Inst-Econ-Res.html 


\title{
Market Concentration in Europe: Evidence from Antitrust Markets*
}

\author{
Pauline Affeldt, ${ }^{\dagger}$ Tomaso Duso, ${ }^{\ddagger}$ \\ Klaus Gugler\$ Joanna Piechucka, $\mathbb{I}$
}

First Draft: October 2019

This draft: January 20, 2021

\begin{abstract}
An increasing body of empirical evidence is documenting trends toward rising concentration, profits, and markups in many industries around the world since the 1980s. Two major criticisms of these studies is that concentration and market shares are poorly measured at the national industry level while firm level revenues are a poor indicator of product sales. We use a novel database that identifies over 20,000 product/geographic antitrust markets affected by over 2,000 mergers scrutinized by the European Commission between 1995 and 2014. We show that concentration, as measured by the market-specific post-merger HHI, is larger than reported in the extant literature (at least) by a factor of ten. We also show that concentration has increased over time on average. Yet, there is a great deal of heterogeneity across geographic markets and within broader industries. In a regression analysis that exploits this within-industry variation, we show that barriers to entry are unambiguously positively related to concentration irrespective of time periods, sectors of activity, and geographical market dimension analyzed. Strict past merger enforcement negatively correlates with concentration. Yet, this effect is stronger in the earlier decade (1995-2004) than subsequently. Intangibility of investments consistently displays positive correlation with concentration only for EU wide and worldwide services markets. In contrast, the correlation is negative in national markets. This underscores the importance of the large heterogeneity present in concentration developments across markets.
\end{abstract}

Keywords: Concentration, HHI, Market Definition, Entry Barriers, Mergers, Merger Control, Intangibles

JEL Codes: L24, L44, K21, O32

\footnotetext{
*The authors thank Thomas Philippon, Florian Szücs, as well as seminar participants at DIW Berlin and the Workshop of the Bertelsmann Foundation and Monopoly Commission on "Market power trends in Germany and Europe" for useful comments and Adam Lederer for proofreading. Pauline Affeldt and Tomaso Duso gratefully acknowledges support from the Berlin Centre for Consumer Policies (BCCP). ${ }^{\dagger}$ DIW Berlin, Technische Universität Berlin, and BCCP. E-mail: paffeldt@diw.de.

${ }^{\ddagger}$ DIW Berlin, Technische Universität Berlin, CEPR, CESifo, and BCCP. E-mail: tduso@diw.de.

${ }^{\S}$ Vienna University of Economics and Business. E-mail: klaus.gugler@wu.ac.at.

${ }^{\mathbb{I}}$ DIW Berlin and BCCP. E-mail: jpiechucka@diw.de.
} 


\section{Introduction}

The literature on the rising trends of market concentration, markups, and profits as well as the declining shares of labor and investment is quickly growing. Gutiérrez and Philippon (2018), Grullon et al. (2019), and Philippon (2019) find that concentration has increased in the US more than in the EU in several industries. Bajgar et al. (2019), Bajgar et al. (2020), and Crouzet and Eberly (2019) find that concentration has increased both in the EU and the US. De Loecker et al. (2020), De Loecker and Eeckhout (2018), and Calligaris et al. (2018) report increasing markups both in the US as well as globally. Autor et al. (2020) find a drop in the labor share (and a rise of mark-ups), whereas Crouzet and Eberly (2019) and Gutiérrez and Philippon (2018) report declining investment in physical capital.

While the diagnosis appears to be unambiguous across authors, the reasons for their findings and, consequently, the suggested therapy, differ widely. Broadly speaking, the economics profession is split into two fields, although most papers take a more nuanced approach: On the one hand, there are those authors who believe that concentration as well as rising markups and profits are "good," since they are a manifestation of efficiency and superior technology due to new inventions and adoption of innovations. On the other hand, there are those authors who believe that rising concentration as well as increasing markups and profits are "bad," since they are a manifestation of rising market power, the strategic erection of market entry barriers, and, ultimately, of a less dynamic economic environment and declining productivity. ${ }^{1}$

Most notably, Autor et al. (2020) - proponents of the first group of authors - attribute the drop in the labor share to the rise in "superstar firms," with their unmatched efficiency, capital deployment, and network effects, leading to "winner takes all" or "winner takes most" markets. Along these lines, Hsieh and Rossi-Hansberg (2019) find that sectors in which national concentration is rising have increased their share of employment, and the expansion is entirely driven by the number of local markets served by (top) firms. Crouzet and Eberly (2019) explain much of the rise in concentration and the weakness in physical capital investment since 2000 by "intangible capital" (i.e. software, intellectual property, brand, and innovative business processes), most of which is "scalable." Furthermore, Tambe et al. (2020) show that "superstar firms" accumulated a disproportionately large amount of digital capital and this well predicts their productivity. Proponents of the other side, such as Gutiérrez and Philippon (2018) and Grullon et al. (2019), view rising concentration as the result of a lack of antitrust enforcement implying higher margins and more profitable M\&As, with no evidence of increased efficiency. De Loecker et al. (2020), De Loecker and Eeckhout (2018), and Calvino et al. (2018) report large heterogeneity in concentration trends (increases driven by firms at the top of the distribution, and higher in digital-intensive sectors), but also view market power as one of the main reasons for increased margins.

Needless to say, the suggested remedies differ markedly according to the suggested diagnosis. Proponents of the "good" side of rising concentration generally suggest a role for the

\footnotetext{
${ }^{1}$ Or to put it in the words of Shapiro (2018, p. 737), "Profits necessary to induce risky investments are one thing; incumbency rents are quite another."
} 
state to invest in better education systems, integrated markets to reap economies of scale, and better functioning capital markets to finance non-collateralizable assets with more equity. Proponents of the "bad" side of rising concentration generally suggest a greater role for competition authorities in merger control as well as in the enforcement of the rules against monopolization and the abuse of dominant positions.

In this study, we question the very premise of this literature since we view the starting point - rising concentration - as not yet proven. In particular, we question the validity of concentration measures based on industry classifications and/or on firm balance sheet data, as used by the aforementioned literature. Market definition should be based on the concept of substitution among products competing in the market (Berry et al., 2019). We argue and show that the extant literature has failed, as it did not provide statistics based on this fundamental logic, and that we can arguably fill this gap. ${ }^{2}$ A major criticism of these studies is that market shares are measured at the national industry level and revenues at the firm level because economic markets as well as product level revenues are generally not observed directly in the data. Indeed, both the "numerator" (product level sales) as well as the "denominator" (sum of sales in the relevant product as well as geographic market) might not - and generally do not - reflect economically sensible definitions. Additionally, using more disaggregated data, such as census data, at the regional level does not completely solve this problem as market definition often does not coincide with geographic boundaries.

We use a novel database that identifies over 20,000 product/geographic antitrust markets affected by over 2,000 mergers scrutinized by the European Commission between 1995 and 2014 to achieve the "well-nigh" impossible task of measuring concentration consistently on an economy-wide basis over time. ${ }^{3}$ Crucially, this dataset uses the Commission's market definition, which is developed during its merger investigations. Thus, not only does it arguably define both the relevant antitrust markets in its product and geographic dimensions properly (i.e. the "denominator"), it also accounts for the proper sales of the firm (i.e. the "numerator") to calculate market shares. Market shares are not only calculated for the merging parties but also for the most important competitors. Thus, if one believes in the EU Commission judgements on market definition and market shares, ${ }^{4}$ this is the most comprehensible database on (antitrust relevant) market shares of firms across and within industries.

While we show that concentration - as measured by the market-specific Herfindahl-Hirschman index (HHI) - has indeed increased over time, there is a great deal of heterogeneity across several dimensions. First, concentration appears to have increased more in broad world-wide markets than in more narrowly defined national markets. Moreover, concentration seems to

\footnotetext{
${ }^{2}$ To cite again Shapiro (2018, p. 722), "One unavoidable and persistent problem is conceptional: defining relevant markets in which to measure market shares is known to be difficult in individual antitrust cases, and is well-nigh impossible to do consistently on an economy-wide basis."

${ }^{3}$ The original database identifies over 30,000 product/geographic antitrust markets affected by over 5,000 mergers scrutinized by the European Commission between 1990 and 2014 (see Affeldt et al., 2018). We lose observations due to missing values on some of key variables.

${ }^{4}$ The DG Competition of the EU Commission is one of the (some observers say "the") best performing antitrust authorities in the world, so we argue that they provide one of the best possible sources to get the right market definition.
} 
have increased more in the service sectors than in manufacturing. Even within these broad sectors, we observe quite some heterogeneity across and within industries. To exploit this variation and identify significant correlates to concentration, we use a regression framework. Barriers to entry are unambiguously positively correlated with concentration, irrespective of time periods, sectors of activity, and geographical market dimension analyzed. Although, strict past merger enforcement negatively correlates with concentration, it appears that this correlation was stronger in the earlier decade (1995-2004) than thereafter. Intangibility of investments displays a consistent positive correlation with concentration only for wider than national - EU wide and worldwide - services markets. In contrast, it is negatively correlated with concentration in national markets.

We are aware of the fact that our data suffer from (at least) two kinds of selection issues. On the one hand, we sample only those markets that are affected by large horizontal mergers. On the other hand, among these markets, we only observe market shares when DG Comp reports them. Arguably, this may happen in potentially more "problematic" mergers and, therefore, more concentrated markets. We tackle these two selection issues with two remedies. First, we include in the regressions a set of variables capturing the prevalence of mergers in the respective industry during the previous 12 months, which should control for the extent of merger waves (Andrade et al., 2001; Clougherty et al., 2016). Thus, we condition concentration effects of our variables of interest on the likelihood of observing mergers. Second, in robustness tests, we estimate Heckman two-step selection models to account for the likelihood that the EC reports market shares.

Section 2 analyzes why the extant literature is wrong to use industry level as well as firm level balance sheet data to calculate market shares in an antitrust sense. We argue that there is no way to sign the direction of the bias, i.e. so calculated market shares could be too large or too small. Empirically, we find that concentration measures in the literature are easily smaller by a factor of ten than our - arguably - correct measures. Thus, even robustness tests (e.g. using 6-digit instead of 4-digit industries; using segment or subsidiary sales instead of firm level sales) or other adjustments (e.g. accounting for exports or imports) cannot bound the problem. Section 3 describes the EU merger database as well as all other data sources used (e.g. the EU KLEMS database). Section 4 describes the key variables used in our empirical analysis - specifically the geographic and product extent of the market definition as well as the measures of markets shares and concentration. This section also discusses important caveats with our data and the issues of sample selection mentioned above. Section 5 provides a descriptive analysis of concentration trends over time in the aggregate, across geographic market definitions (national, EU wide and worldwide), and across broad sectors of activity (manufacturing versus service sectors). Section 6 further analyses these patterns of concentration using regression analysis. The last section concludes. 


\section{Measurement of Concentration}

\subsection{The Concept of Relevant Markets}

Notwithstanding the intense debate among academics, competition policy experts, as well as practitioners, the definition of the "relevant market" - along both the product and geographic dimensions - remains a key step of any antitrust analysis as it constitutes the fundamental base for calculating the structural indicators of competition, including market shares and concentration indexes. Both the European Commission's (EC) 2004 Horizontal Merger Guidelines as well as the US 2010 Horizontal Merger Guidelines still recognize that the level and the changes in market shares and concentration measures are helpful indicators that can be used, among others, to assess the likely competitive effect of a merger or judge on the existence of a dominant position (e.g. Fletcher and Lyons, 2016). ${ }^{5}$

Looking at the European experience, the focus of this paper, the 1997 Notice on Market Definition was one of the earliest and most fundamental guidelines the EC gave for merger control. The Notice recognizes the need to base the definition of the relevant market on substitution patterns across product and geographical dimensions; the most important being demand side substitution and - to a lesser extent - supply-side substitution. Instead, potential competition is not considered at the market definition stage but at the stage of competitive assessment. ${ }^{6}$ This is - as we argue below - in contrast to industry or sector classifications that group products according to their production processes, characteristics or external appearance.

\footnotetext{
${ }^{5}$ The discussion on the usefulness of these structural indicators in antitrust goes back at least to the late 1980s. The main issues with the use of a concentration-based approach concern both the difficulty of cleanly identifying which products are substitutes of each other and, thus, directly competing in the relevant market, as well as the theoretical underpinning of concentration indexes as measures of competition and market power. This approach is particularly criticized in markets with differentiated products where the theory of harm is related to unilateral effects. The discussion was heavily influenced by the development of the so-called structural approach proposed by the new empirical industrial organization literature, which questioned the use of industry-level concentration measures as proper indicators of competition (e.g Bresnahan and Schmalensee, 1987; Bresnahan, 1989), as well as early work using first-order approaches to assess the potential effects of mergers (e.g Hausman et al., 1994; Werden, 1996). This discussion stresses the fact that the definition of the relevant market might not be necessary and the competitive assessment of a merger could circumvent it. It also eventually led to the introduction of new concepts in antitrust enforcement such as the notion of "upward pricing pressure" (UPP) (Farrell and Shapiro, 2010) that are proposed as a practical and theoretically sounder alternative tool to concentration-based methods. These developments had a significant policy impact and became, for instance, an important element of the US 2010 Horizontal Mergers Guidelines.

${ }^{6}$ As EU Competition Commissioner Vestager mentioned in her speech on December 9, 2019, (https://ec.europa.eu/commission/commissioners/2019-2024/vestager/announcements/defining-marketsnew-age_en) "What we do when "defining" markets is to study the complex interplay between product characteristics, customer and supplier behaviour, firms' substitution decisions and regulation. And on this basis we try to answer the question: Can customers turn to someone else if prices go up, quality down or innovation stops?" In 2021, the EC is reviewing the Market Definition Notice to account for structural changes, such as globalization and digitization, that might have impacted the way markets work and address criticisms concerning both the geographic dimension of markets as well as the product market definition.
} 


\subsection{How Not to Measure Concentration}

In what follows, we argue that industry classifications at the national level and firm-level accounting data, which have been used in the aforementioned literature, do not give reasonable bounds to market shares, i.e. they are simply wrong for use in an antitrust sense (e.g. Berry et al., 2019). This point is already stressed in the current policy debate about the rise of concentration (e.g Wright, 2018). To substantiate this point, Werden and Froeb (2018), looking at the US experience, show that even the quite disaggregated United States Census data are (mostly) excessively aggregated and this has severe implications for understanding the true changes in concentration in well-defined relevant antitrust markets. By looking at specific merger cases filed by the Justice Department from 2013 to 2015, they argue that the increases in concentration seem to be modest in a handful of sectors. But why exactly is the current literature focusing on increasing concentration and margins wrong on the measurement of such statistics?

Definition of the relevant product market. Industry classifications of products may be either too large or too small in an antitrust sense. Industry classifications may be too large since they include products that may not be substitutes, and they may include suppliers and customers, and not only competitors. Standard industry classifications, including NACE and SIC, as well as the U.S. Census, group products according to their production processes or characteristics and generally do not capture substitutive relations. ${ }^{7}$ By way of an example, Table 1 depicts the aircraft industry broken down to the 8-digit SIC level. The plight of using this classification already becomes evident when looking at the total number of establishments $(2,440)$ operating in the US. To cite, the classification includes:

"Establishments primarily engaged in manufacturing or assembling complete aircraft. This industry also includes establishments owned by aircraft manufacturers and primarily engaged in research and development on aircraft, whether from enterprise funds or on a contract or fee basis. Also included are establishments engaged in repairing and rebuilding aircraft on a factory basis."

Thus, this classification fails utterly in capturing sensible antitrust relations in both the product market as well as the geographical market dimensions. Our EU merger database, on the other hand, would correctly define markets in both dimensions. In that example, it would put Boeing and Airbus into the same relevant product market of e.g. wide body aircraft, or Boeing, Airbus, Bombardier, and Embraer into "regional jets," etc. Moreover, it would define the relevant geographical market as worldwide and not national as the industry classification above does.

Using more detailed industry classifications, e.g. 6- or 8-digit, does not solve the problem. To make things worse, industry classifications may overstate substitution but may at the

\footnotetext{
${ }^{7}$ Ali et al. (2008) criticize using standard databases such as Compustat to define markets on the grounds that concentration measures essentially do not correlate with concentration measures using corresponding U.S. Census measures. We actually go one step further and also criticize using U.S. Census data for antitrust purposes, since the Census also uses industry classifications to define markets and, therefore, its data potentially suffer from the same problems.
} 
same time be too small, since they may not include relevant substitutes (e.g. planes and trains; fixed vs mobile telecom, etc.).

Table 1: Aircraft Industry - Different levels of aggregation

\begin{tabular}{|c|c|c|}
\hline Codes & Titles & Total US Businesses \\
\hline 3721 & Aircraft & 2,440 \\
\hline 372100 & Aircraft & 1,437 \\
\hline 37210000 & Aircraft & 1,437 \\
\hline 372101 & Motorized aircraft & 814 \\
\hline 37210100 & Motorized aircraft & 447 \\
\hline 37210101 & Airplanes, fixed or rotary wing & 257 \\
\hline 37210102 & Helicopters & 110 \\
\hline 372102 & Nonmotorized and lighter-than-air aircraft & 57 \\
\hline 37210200 & Nonmotorized and lighter-than-air aircraft & 6 \\
\hline 37210201 & Airships & 5 \\
\hline 37210202 & Balloons, hot air (aircraft) & 15 \\
\hline 37210203 & Blimps & 5 \\
\hline 37210204 & Dirigibles & 5 \\
\hline 37210205 & Gliders (aircraft) & 6 \\
\hline 37210206 & Hang gliders & 15 \\
\hline 372199 & Aircraft, nec & 132 \\
\hline 37219901 & Autogiros & 13 \\
\hline 37219902 & Research \& development on aircraft by the manufacturer & 119 \\
\hline
\end{tabular}

Definition of the relevant geographic market. Similar to the product market dimension, the geographic dimension of national industry-level aggregates may also be either too large or too small. They may be too small if relevant markets are actually at a supra-national level (such as worldwide or other groups of countries) or they may be too large if markets are actually more local than national. Accounting for imports and/or exports does not solve the problem, since from the databases at hand one cannot judge which geographical market is the correct one. Even if one knows which countries should be included in, or excluded from, the relevant market, one does not know which parts of imports or exports should be included. ${ }^{8}$

Firm sales data. Firm sales data are also not well suited to measure market shares at the relevant-market level. Firms' individual market shares may be too large if firms are diversified with sales across many e.g. 4-digit industries. Allocating sales to one industry then overestimates market shares. At the same time, they may be too small if the group structure of firms (e.g. subsidiaries) is not accounted for. Consequently, firm sales data will not allow for capturing the size of the market at the relevant-market level. Both the "numerator" and the "denominator" will be affected and measure total sales of the relevant firms concerned across all their products rather than on the relevant market.

The above discussion makes clear that industry classifications and balance sheet data are not suitable for calculating market shares and other concentration measures, since it is not clear what they measure. Therefore, robustness checks and re-classifications are also, more

\footnotetext{
${ }^{8}$ See the long discussion by Fletcher and Lyons (2016), p.13-15, on whether or not and, if yes, to what extent imports/exports should be included in the relevant geographic market. Generally, the criterion should be whether these trade flows can discipline producers in the candidate area in the event of price increases.
} 
or less, pointless. Our contribution is to look at antitrust relevant product markets (not industries) as well as relevant geographic markets (not national boundaries). We next turn to our databases.

\section{Data}

\subsection{Data Sources}

EU Merger Database. We utilize the entire population of merger decisions by DirectorateGeneral for Competition (DG Comp) of the EU Commission for the 1990-2014 period (Affeldt et al., 2018). Merger cases and their decisions are publicly accessible and published by DG Comp on the EC's website. Each decision (between 20 and more than 400 pages) was carefully read and, for each merger, the following information was codified: the merging parties and their rivals in each product/geographic market defined by DG Comp, which the merger affects (each merger affects one or more product/geographic markets); the market shares of all firms, if available; whether the market is defined at the national/local, EU wide or worldwide level, or whether the extent of the geographical market was left open. Moreover, we codify important characteristics of the Commission's decision at the level of the affected markets, e.g. whether the Commission raised competitive concerns in the respective relevant market, whether the merger had (also) vertical or conglomerate aspects, whether the Commission saw significant entry barriers or whether there was a risk of foreclosure in the market.

The full data set covers 5,109 DG Comp merger decisions over the 1990-2014 period giving rise to 30,995 (product/geographic) market level observations.

EU KLEMS Database. We obtain-industry level data on intangible and tangible investment from the EU KLEMS, Growth and Productivity Accounts (release 2019) database described in Stehrer et al. (2019). It provides a database on measures of economic growth, productivity, capital formation, and technological change indicators for the 1995-2017 period for all European Union member states, Japan, and the US. For the analysis, we exploit information on tangible and intangible assets. Specifically, we construct intangible and tangible investment intensity by dividing (in)tangible investment by industry Gross Value Added (GVA), also coming from EU KLEMS. Table 9 in Appendix A.1 provides a description of the level of industry aggregation provided in EU KLEMS.

Worldscope Database. We additionally obtained firm level data from Worldscope. We use this data to construct additional time-varying industry controls. In particular, we construct yearly mean industry-specific variables for the EU KLEMS industries. ${ }^{9}$ Table 10 in Appendix A.2 contains a list of the industry controls included in the final data set. Note that we express all these variables as mean yearly percentage changes.

Sample Construction.First, we only consider those (product/geographic) market level observations with (at least some) market share data (ca. 74\%) from the EU merger database. Second, in order to match the EU merger (market share) data with industry level information

\footnotetext{
${ }^{9}$ For each firm and year observation, we first calculate the percentage change for a given variable as: $\left(v a r_{t}-\right.$ $\left.v a r_{t-1}\right) / v a r_{t-1}$. We then calculate the yearly mean of these percentage changes within a KLEMS industry by weighting each firm by its share of total assets in the year/KLEMS cluster.
} 
(e.g. intangible capital intensity) from EU KLEMS (time coverage: 1995-2017), we place each of the identified antitrust markets in one of the KLEMS industries. We do this by using the information provided by the EC on the NACE industries affected by the merger. Thus, the unit of observation in our analyses is one specific product/geographic market, in a given KLEMS industry, in a given year. The final samples result from the overlap of these two datasets. Some observations are missing due to absent information on specific variables. The final dataset covers the 1995-2014 period and contains 21,109 (product/geographic) market level observations with (at least) market share data on the merging parties and 9,346 (product/geographic) market level observations with market share data also on at least one rival.

One criticism of EU merger control focuses on the claimed tendency of the Commission to define geographic markets too narrowly in a world where competition should be increasingly defined at a global level. Taking a look at the data, we observe that, over the entire sample period, $64 \%$ of relevant markets have been defined by DG Comp as national, $25 \%$ as EU wide, $11 \%$ as worldwide. In Figure 1, we analyze the evolution of the geographic market definition over time. Apparently, the abovementioned criticism does not seem to have a strong bite. The share of markets that have been defined to be national in nature fluctuates between about $70 \%$ in 2003 and below $50 \%$ in 2012. If at all, excluding the last year of the sample, there seems to be a tendency over time to define markets more widely. We shall see that the geographic market definition is a very important dimension to explain concentration dynamics.

Figure 1: Evolution of geographic market definition over time

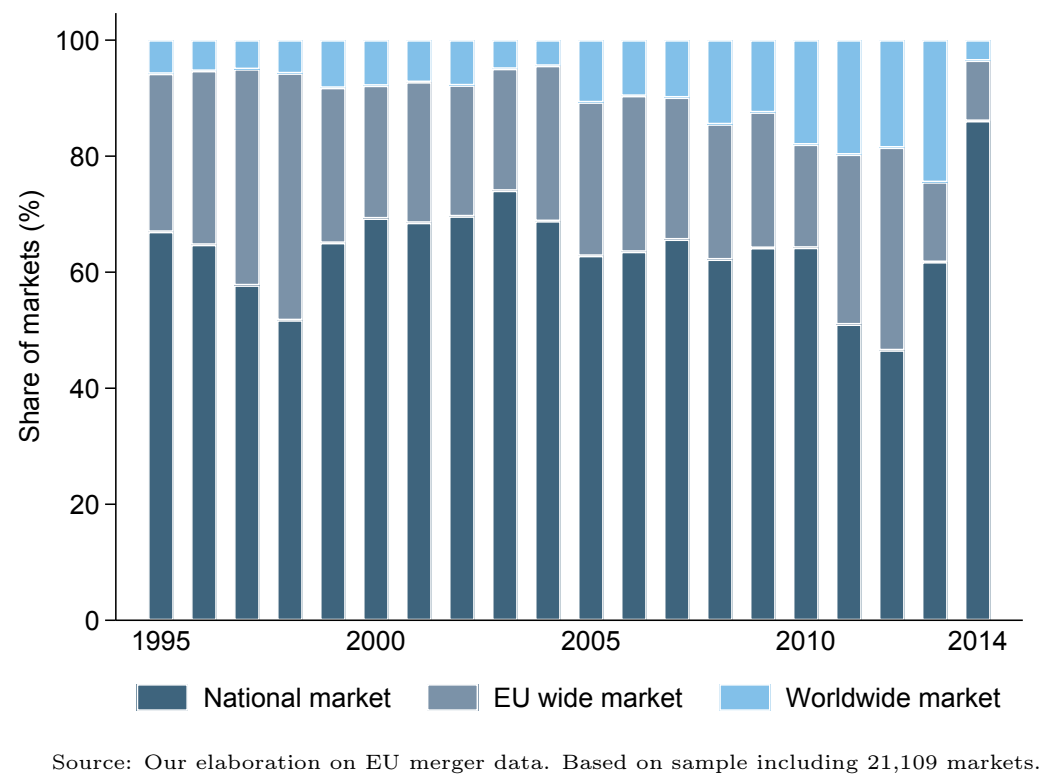

\subsection{Market Shares \& Concentration measures}

We measure concentration by the Herfindahl-Hirschman Index (HHI), defined as the sum of squares of all available market shares. We obtain market shares for at least the merging 
parties for ca. $74 \%$ of the markets. In our final sample, however, in $43 \%$ of cases the Commission reports only the joint market shares for the merging parties, but it does not separately outline the market shares of acquirers and targets. This is why we concentrate on what we call "post-merger" HHI as we always consider the new merged entity rather than the separate entities pre-merger, when calculating concentration indexes. In around $44 \%$ of the markets, the Commission defined at least one (major) competitor. Because of this partially incomplete reporting, the sum of the market shares does not always equal $100 \%$ in all markets. Thus, our concentration measure represents a lower bound of the true HHI. ${ }^{10}$ Finally, market shares are mostly reported in intervals, e.g. [15-20] percent. We take the midpoints. ${ }^{11}$

Table 2: Summary Statistics of Continuous Variables at Market Level - final sample

\begin{tabular}{|c|c|c|c|c|}
\hline Variable name & Level of detail & Mean & $\mathrm{SD}$ & $\mathrm{N}$ \\
\hline \multirow[t]{4}{*}{ Joint market share } & Market-level obs. with (non-zero) MS & 33.0 & 23.5 & 21,109 \\
\hline & Market-level obs. with MS of rivals & 36.6 & 21.1 & 9,346 \\
\hline & Market-level obs. on Phase II mergers & 44.3 & 22.9 & 1,699 \\
\hline & Market-level obs. on Phase I mergers & 34.9 & 20.3 & 7,647 \\
\hline \multirow{3}{*}{ Market share of rivals (average) } & Market-level obs. with MS of rivals & 18.5 & 13.2 & 9,346 \\
\hline & Market-level obs. on Phase II mergers & 18.6 & 14.2 & 1,699 \\
\hline & Market-level obs. on Phase I mergers & 18.5 & 13.0 & 7,647 \\
\hline Post-merger HHI (low) & Market-level obs. with (non-zero) MS & $2,182.3$ & $2,358.1$ & 21,109 \\
\hline \multirow[t]{4}{*}{ Number of firms } & Market-level obs. with (non-zero) MS & 4.1 & 2.5 & 21,109 \\
\hline & Market-level obs. with MS of rivals & 5.6 & 2.2 & 9,346 \\
\hline & Market-level obs. on Phase II mergers & 5.2 & 2.2 & 1,699 \\
\hline & Market-level obs. on Phase I mergers & 5.7 & 2.2 & 7,647 \\
\hline
\end{tabular}

Source: Our elaboration on EU merger data.

Table 2 displays summary statistics for the different measures from the EU merger database used to construct concentration indexes. These statistics are reported for different samples. While, for each statistic, the first line represents the values in the sample for which we have at least the market shares of the merging parties, the second line represents the sample used in the regressions where we also have the market shares of at least one competitor. We also report the values for the samples of phase II cases and for mergers closed in the first investigation phase. This should give a better idea of the potential selection entailed in the various sub-samples considered later in the empirical execution.

\footnotetext{
${ }^{10}$ In our final sample, the sum of available market shares averages $58.6 \%$. Therefore, in a robustness check, we allocate the missing market shares to a hypothetical entity, thus creating a sort of upper bound to the concentration measure. Regression results based on this alternative measure do not change qualitatively.

${ }^{11}$ When market shares are reported in intervals of five percentage points, we take the lower bound. See Affeldt et al. (2018) and Affeldt et al. (2020) for a discussion.
} 
The average market share of the joint market shares of the merging parties is $33 \%$ in the full sample and it increases to $36.4 \%$ in the restricted sample used in the regressions. The average market shares of the competitors is, instead, lower at around $19 \%$. The average post-merger HHI is as high as 2,192 points in the full sample and it rises to over 3,000 points in the main sample used in the regression. Concentration is higher in (competitively more problematic) phase II mergers $(3,664)$ than in phase I mergers $(2,870)$. We observe on average 4 firms competing in the relevant markets in the full sample which increases in the regression sample to 5.6 competing entities in the relevant product/geographic market.

These statistics are already quite informative on the state of the current debate. Indeed, average antitrust markets are much more concentrated than suggested by the extant literature using industry classifications and balance sheet data to define markets. For example, Ali et al. (2008) report average HHIs at the 6-digit NAICS level of 64 using Census data and 696 using Compustat data from 1980 through 2005. Gutiérrez and Philippon (2018) report, in their Figure 28, weighted average EU HHIs across the four sources KLEMS08, Compustat, CompNET, and ORBIS of around 10 to 80 with market definition being between the digit levels 2-3. Crouzet and Eberly (2019) report in their Figure 9 average HHIs of between 100 and 250. At the higher end of estimates, Autor et al. (2020) report figures for CR4 of around $40 \%$ using Census data, Bajgar et al. (2020) of 40-44\% for CR8, and Bajgar et al. (2019) get an average CR8 of around $25 \%$ in Europe and $38 \%$ in North America. ${ }^{12}$

Our measures at the relevant product/geographic markets show that sensibly defined antitrust markets are much more concentrated than those reported by the literature. The question is then whether one can trust trends in concentration measured by those variables used in the literature so far? The answer is probably not. If a measure is mis-measured by a factor of ten, it is unlikely that its evolution might capture sensible dynamics in an antitrust relevant setting. Thus, we do not know what the literature so far really measured: maybe the size of the firm; diversification/expansion in (nearby) product or geographical markets ${ }^{13}$, perhaps even something else. However, we do know that what the literature measured so far is not sensibly related to antitrust markets.

For the rest of the paper and, in particular, for our empirical analysis, we focus on the sample of 9,346 antitrust markets for which we have information on market shares for the merging firms as well as their competitors. Table 3 reports the preliminary statistics for the main variables used in the descriptive and econometric analysis. For each variable, we report statistics for the full sample and the sub-samples determined by the market definition.

Entry is measured by a dummy variable taking on the value of one if the EU Commission identified significant barriers to entry in the respective relevant market. This is the case in between $14 \%$ and $25 \%$ of the markets, depending on the geographic market definition. Entry barriers reflect DG Comp's assessment of the existence of entry barriers in the relevant market. This is an assessment of the competitive situation in the market prior to the merger

\footnotetext{
${ }^{12}$ Many papers (e.g. Hsieh and Rossi-Hansberg, 2019; Rossi-Hansberg et al., 2020; Foerster et al., 2019; Grullon et al., 2019) do not even bother to report average concentration levels but only changes in concentration measures in percent (not percentages!) or correlations with other measures.

${ }^{13}$ Hsieh and Rossi-Hansberg (e.g. 2019) find that 93\% of the growth in concentration comes from growth in the number of cities served by top firms.
} 
and as such also reflects "lagged" entry barriers. Past industry merger activity is defined as the number of merger notifications in the respective industry (EU KLEMS industry) in the previous 12 months relative to the notification date. On average, between 5 and 6 mergers are notified per industry and year, depending on the geographic market definition considered. Past industry merger control enforcement measures the percentage of mergers where DG Comp intervened (either blocked the merger or imposed remedies on it - what we call "actions") in the two years before the merger within an EU KLEMS industry group. ${ }^{14}$ The industry enforcement ratio is lowest in EU wide markets (15\%) and highest in worldwide markets (28\%). Finally, intangible assets intensity is defined as average investment in intangible assets as percentage of Gross Value Added (GVA) across countries by industry-year. ${ }^{15}$ Intangibles represent on average $12 \%$ of GVA.

Table 3: Summary statistics - key variables

\begin{tabular}{|c|c|c|c|c|c|c|}
\hline Variable name & Geog. market definition & Mean & $\mathrm{SD}$ & Min. & Max. & $\mathrm{N}$ \\
\hline Post-merger HHI (low) & EU wide & $2,524.43$ & $1,615.02$ & 50.00 & $10,000.00$ & 2,435 \\
\hline \multirow[t]{3}{*}{ Barriers to entry at market level } & National & 0.24 & 0.42 & 0.00 & 1.00 & 5,713 \\
\hline & EU wide & 0.14 & 0.34 & 0.00 & 1.00 & 2,435 \\
\hline & Worldwide & 0.25 & 0.43 & 0.00 & 1.00 & 1,198 \\
\hline Ave. industry enforcement ratio $(\mathrm{t}-1) /(\mathrm{t}-2)$ (in \%) & National & 18.17 & 19.69 & 0.00 & 100.00 & 5,713 \\
\hline \multirow[t]{3}{*}{ Merger wave ( $\mathrm{N}$ of decisions in $(\mathrm{t}-1)$ ) } & National & 5.98 & 4.60 & 0.00 & 20.00 & 5,713 \\
\hline & EU wide & 6.41 & 4.87 & 0.00 & 23.00 & 2,435 \\
\hline & Worldwide & 4.51 & 4.30 & 0.00 & 22.00 & 1,198 \\
\hline \multirow[t]{3}{*}{ Intangibles to VA (in \%) } & National & 12.61 & 6.69 & 0.77 & 35.41 & 5,713 \\
\hline & EU wide & 11.54 & 5.74 & 0.58 & 35.41 & 2,435 \\
\hline & Worldwide & 11.21 & 5.90 & 1.36 & 35.41 & 1,198 \\
\hline
\end{tabular}

In Appendix A.3, we report figures depicting the evolution of these four variables over time by geographical market definition and sector of activity. Entry barriers appear to increase over time although there is no strong tendency (Figure 6). Past merger enforcement became more lenient in EU wide and worldwide manufacturing markets, but more stringent in EU wide and worldwide services markets (Figure 7). Industry merger notifications show no clear tendency over time (Figure 8). Intangible asset intensity generally increases over time, particularly for wider than national (EU wide or worldwide) services markets (Figure 9).

\subsection{Caveats}

Before we turn to our analysis on concentration, we must mention at least two caveats with our data. First, we do not observe a panel of markets over time, but a pooled cross-section over time. Since each observation is one specific product/geographic market affected by a merger, we essentially draw market observations (only) if mergers occur. Since mergers occur in each year and in many industries, we can trace out the evolution of concentration over time

\footnotetext{
${ }^{14}$ The enforcement ratio is defined as [actions $(\mathrm{t}-2)+$ actions $\left.(\mathrm{t}-1)\right] /[$ notifications $(\mathrm{t}-2)+(\mathrm{t}-1)]$

${ }^{15}$ Average intangible intensity by industry-year is computed by considering countries for which information on intangible investment was provided consistently throughout the whole period of analysis (1995-2014). These are Austria, Czechia, Denmark, Finland, Germany, Italy and Sweden. In addition, Japan was included in the computation when considering worldwide markets.
} 
and across broader industries. For some parts of the analysis, markets are grouped in broad product markets (from the Commission's files, e.g. air transport \& travel, electrical appliance, pharmaceuticals) as well as industries according to EU KLEMS definition (41 industries). Within these broad industries, we measure correct market shares and concentration at the antitrust market level.

Second, obviously we suffer from two kinds of selection issues. On the one hand, we sample only those markets that are affected by horizontal mergers, and on the other hand, among these, we observe market shares only when DG Comp reported them, which may happen in potentially more "problematic" mergers and, therefore, more concentrated markets.

In the regression analysis, we tackle the two selection issues with two remedies. First, we include in the regressions a variable capturing the prevalence of mergers in the respective industry during the previous 12 months as well as several variables that might be related to the existence of a merger wave. Thus, we condition the effects of our variables of interest on concentration on the likelihood of observing mergers in a given industry. Second, in robustness tests we estimate Heckman two-step selection models to account for the likelihood that the EC reported market shares in the analyzed mergers.

In addition, in Section A.4 of the Appendix, we address these caveats by graphically analyzing the coverage of the EU merger database. ${ }^{16}$ We show that nearly all EU KLEMS industries are covered by our database. Further, we provide evidence that the distribution of the number of firms across industries from our EU merger database is similar in shape to the distribution in the Worldscope database.

\section{Descriptive Results}

We start our empirical analysis by describing the evolution of the post-merger HHI on average and distinguishing between different geographic market definition as well as sectors of activity.

Increasing concentration Figure 2 plots our post-merger HHI measure against time. On average, we observe increasing concentration, with average HHI increasing from around 2,500 in the mid-1990s to more than 3,000 in 2014, the last year of the sample. The box plots also show that there is quite some heterogeneity around these mean values and that, possibly, heterogeneity slightly increased over time. This is not necessarily due to an increasing number of observations over time. ${ }^{17}$

The role of geographic market definition Figure 3 displays the important role of the extent of the geographic market definition. Concentration in national markets - while being fairly high already at the beginning of the sample (HHI of around 3000) - does not increase much over the next 20 years. In contrast, EU wide and most prominently worldwide markets, while starting out with much lower levels of concentration, catch up with national markets toward the end of the sample period (EU wide markets) or even become the most

\footnotetext{
${ }^{16}$ Please note that the analyses are undertaken on the sample of 21,109 observations with (non-zero) MS.

${ }^{17}$ Indeed, the green line plots the number of notified mergers in our sample over time. There are two peaks in 2000 and 2007 and a wave pattern that mimics the typical merger-wave patterns observed in the literature based on other merger databases (e.g. Ahern and Harford, 2014)
} 
Figure 2: Evolution of HHI in antitrust markets over time

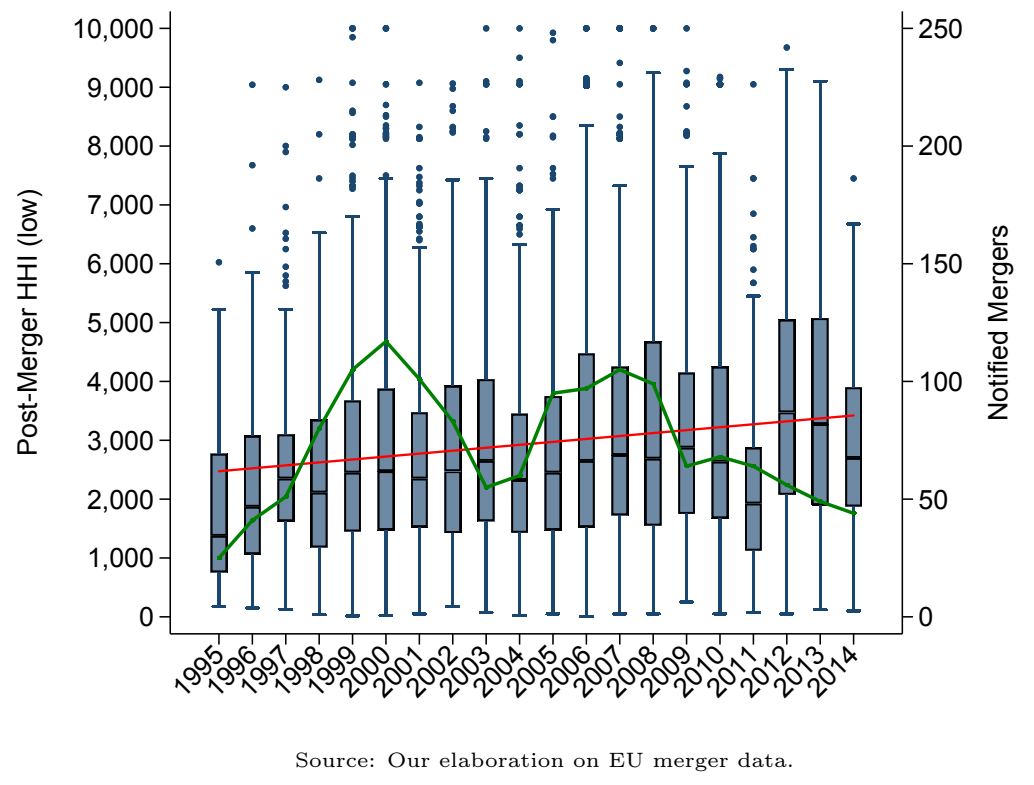

concentrated category of markets by 2014 (worldwide markets with an HHI of around 4000 in 2014). ${ }^{18}$

Manufacturing vs. services Figure 4 distinguishes between relevant markets in manufacturing versus services. Relevant markets in services start out much less concentrated than relevant markets in manufacturing, however, concentration in the service sector increases much faster than concentration in manufacturing over the following 20 years.

Geographic market definition \& manufacturing vs. services Further investigating observed heterogeneity, Figure 5 splits the sample into manufacturing versus services and, additionally, into our three categories of geographic market dimensions: national, EU wide, and worldwide. Concentration in national or EU wide relevant markets in manufacturing increases only slightly, and concentration in worldwide relevant manufacturing markets even decreases. While markets in all three geographic market definitions in services display increases in average HHI, EU wide and, predominantly, worldwide services markets witness the largest increases in concentration over the period 1995-2014.

Summarizing our descriptive analysis, our measures of concentration are much larger than what the literature so far documented. We obtain average concentration measures (HHI) of around 3,000 while most of the literature comes up with numbers being easily smaller by a factor of ten. Using industry classifications and firm balance sheet data does not appear to be the right way to measure concentration. Similar to the extant literature, we report increasing concentration on average, however this average tendency masks substantial heterogeneity across markets. In particular, the extent of the geographic market dimension plays a crucial role. While national markets and markets in manufacturing only show slight increases in concentration or even decreased concentration (worldwide manufacturing) over the 20-year

\footnotetext{
${ }^{18}$ We do not depict the evolution of left open markets, since the geographic dimension is not clear. This category, however, accounts for less than $2 \%$ of our observations.
} 
Figure 3: Evolution of HHI in antitrust markets over time - geographic market definition
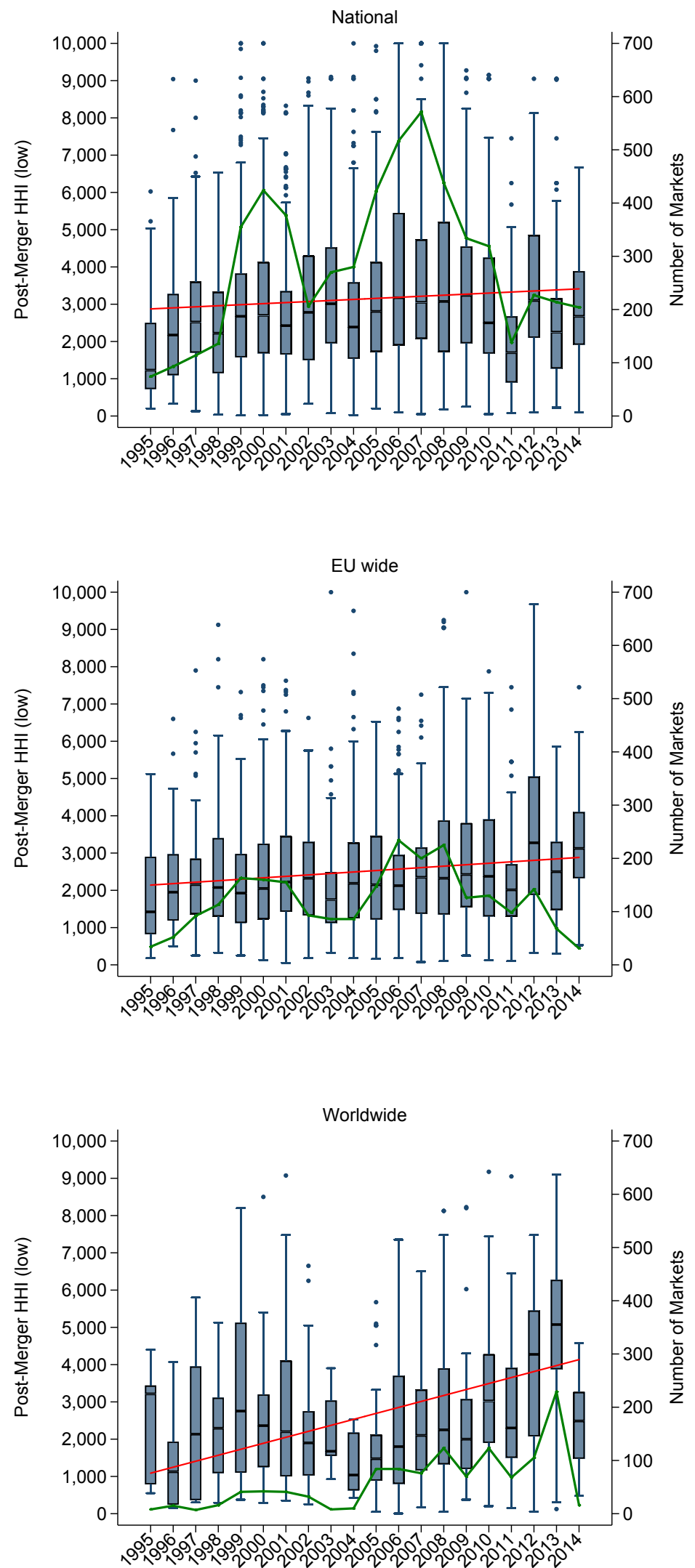

Source: Our elaboration on EU merger data. 
Figure 4: Evolution of HHI in antitrust markets over time - manufacturing vs. services
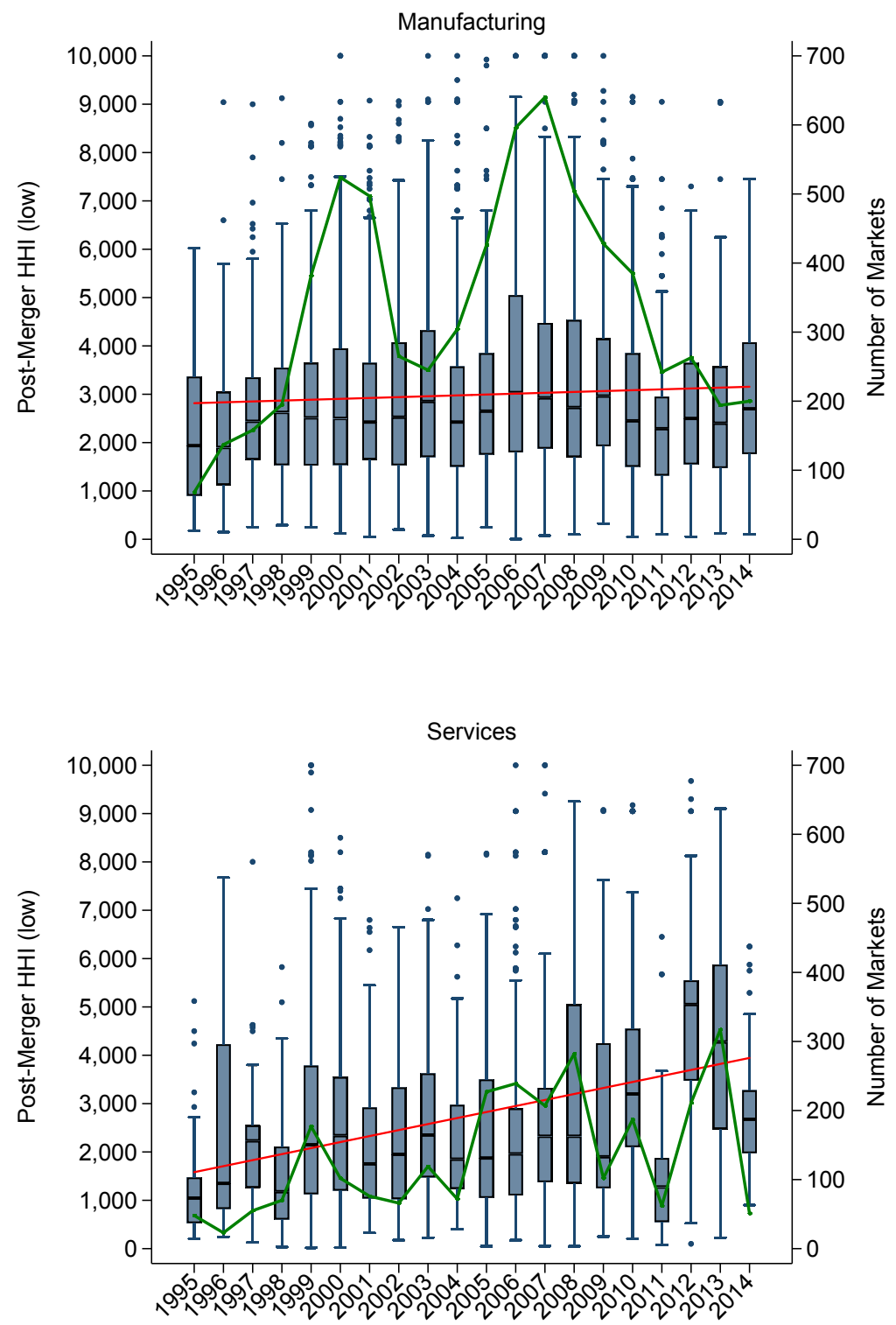

Source: Our elaboration on EU merger data. 
Figure 5: Evolution of HHI in antitrust markets over time - geographic market definition/manufacturing vs. services
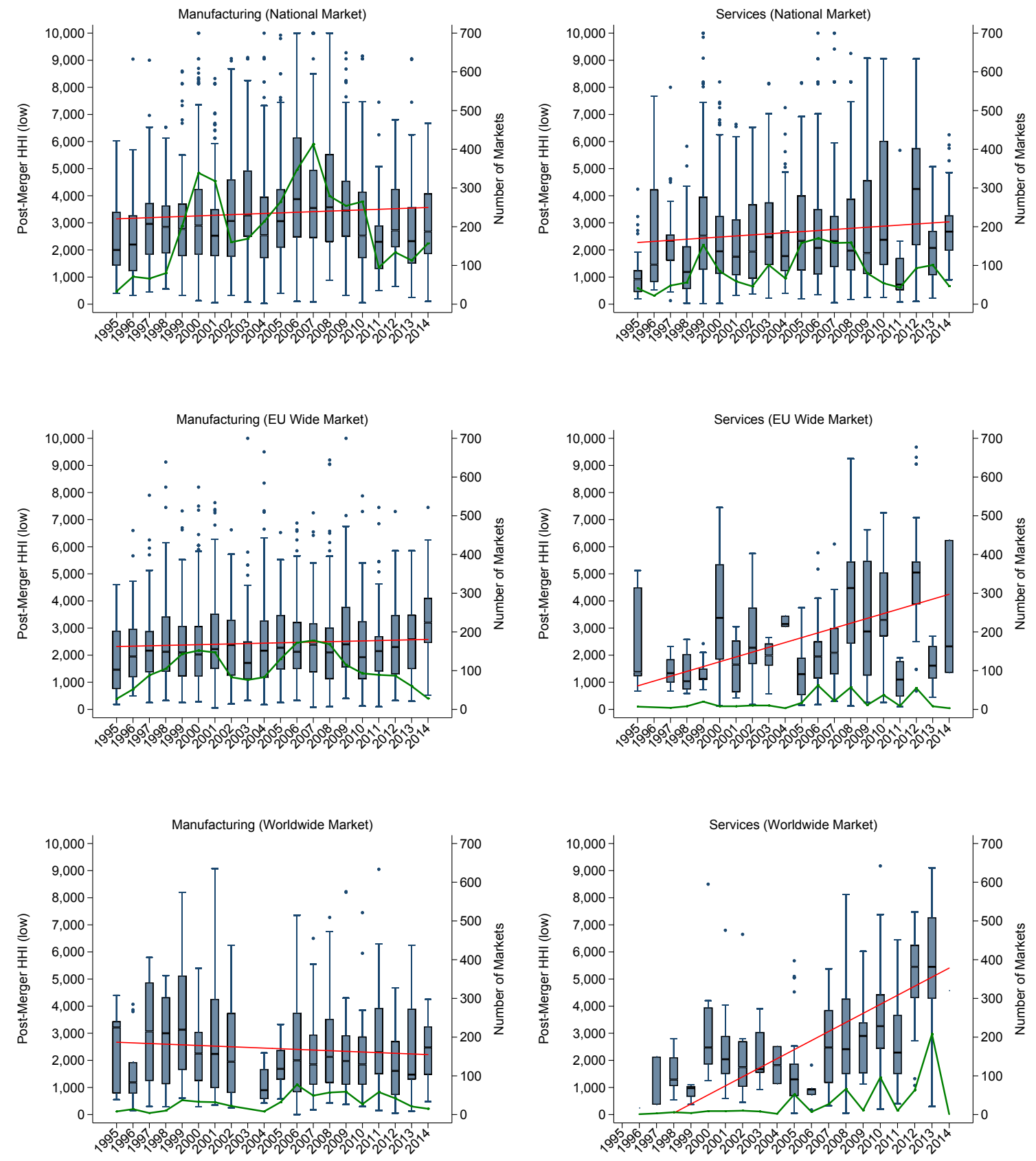

Source: Our elaboration on EU merger data. 
period of 1995-2014, services markets - particularly when they are EU or worldwide in geographic scope - display large increases in concentration. We turn now to regression analysis to explain what might be the driving forces behind this heterogeneity in observed antitrust market concentration.

\section{Econometric analysis}

This section aims to identify the main channels that correlate with concentration in a regression framework controlling for several factors, especially industry and time fixed-effects. We focus on four main potential drivers for the increase in concentration: (1) Entry barriers, (2) Past industry merger activity, (3) Past industry merger control enforcement, and (4) Intangible assets intensity.

Entry barriers should obviously be related to more concentrated markets. Indeed, the likelihood of entry is considered to be one of the most important factors in the analysis of mergers' competitive effects and entry deterrence is long recognized as a driver of market power. ${ }^{19}$ In contrast, more stringent and effective merger control enforcement in the past should have a mitigating effect on concentration (e.g. Duso et al., 2011). Our predictions on past merger activity are ambiguous as this variable serves a dual role. On the one hand, it controls for the selection issue of observing markets in a specific industry only when mergers took place. As such, we have no strong priors on its effect. On the other hand, the economic effect of mergers on concentration is also ambiguous. Increased past merger activity should lead, quasi mechanically, to more concentrated markets. Yet, we may observe much merger activity in less concentrated markets, since targets are abundant and merger control authorities may be more lenient in unconcentrated markets. Thus, we may capture reverse causality, although lagging this variable should, to some extent, partially control for this. Intangibility of assets implies that assets are scalable and technologies are characterized by low marginal and high fixed costs (e.g. Crouzet and Eberly, 2019). If assets become more intangible and, therefore, more scalable over time - and/or if firms invest more in such assets - we would expect that market concentration is positively related to intangible asset intensity in an industry ("winner takes all" or "winner takes most" markets). Moreover, we would expect a more pronounced relation in worldwide markets, since fixed costs can be better spread as well as in services markets, since scalability may be easier. ${ }^{20}$

We run the following regression for market $i$ in industry $j$ in year $t$.

$H H I_{i j t}=\alpha_{0}+\alpha_{1}$ EntryBar $_{i j t}+\alpha_{2}$ Mergers $_{j t-1}+\alpha_{3}$ Enforce $_{j t-1}+\alpha_{4}$ Intang $_{j t}+X_{j t}+\eta_{j}+\eta_{t}+\varepsilon_{i j t}$

where EntryBar ${ }_{i j t}$ denotes barriers to entry in market $i$ in industry $j$ in year $t$. Merger $s_{j t-1}$, Enforce $_{j t-1}$ and Intang $_{j t}$ denote the number of mergers in the previous year, the "actions"

\footnotetext{
${ }^{19}$ See among others Bernheim (1984), Gilbert and Vives (1986), and Waldman (1987).

${ }^{20} \mathrm{~A}$ fortiori, we expect the largest influence of intangibility on concentration in worldwide services markets.

Our hypothesis is also consistent with Sutton's endogenous sunk cost theory (Sutton, 1991).
} 
ratio by DG Comp in the last two years, and intangible investment intensity, all measured at the industry $j$ level.

We look at the determinants of concentration and its heterogeneity through interactions and sub-sampling. In particular, we interact our four variables of main interest with broad sector of activity dummies (manufacturing versus services) and estimate in sub-samples of geographic market definition, i.e. national, EU wide, and worldwide. Different sets of fixedeffects control for unobserved heterogeneity: Year-geographic market definition and yearindustry fixed-effects control for differing compositions of market level observations across time as well as differing broad industry wide trends, respectively. The error terms $\varepsilon_{i j t}$ are assumed to be correlated either at the industry or at the merger level.

As already mentioned, our sample suffers from two types of selection biases. We tackle these issues in two different ways. First, we control for the selection problems induced by over-sampling markets with large merger activity by including in the regressions a variable measuring past industry merger activity (Mergers). Moreover, we also control for other industry-specific time-varying variables that are found to be important drivers of merger waves. ${ }^{21}$

Second, in a robustness check, we estimate Heckman two-step models to account for the possibly endogenous selection of observing market shares only for those mergers that are potentially more problematic (and have larger markets shares) and that were, therefore, looked at in greater detail by the EU Commission. In particular, we analyze whether the sample in which we observe all the market share data (merging insiders and rivals) differs from the sample in which we observe only merging firm market shares. Thus, in the two-step model, we first estimate the selection equation via a probit regression, which estimates the probability of observing rival market shares. The main exclusion restriction consists of using a phase 1 dummy indicating whether the merger was cleared in phase 1 of the merger control procedure. Phase 1 cleared mergers are much less problematic than those mergers that are decided in phase 2. Thus, the Commission has a much lower incentive to look at the merger in depth, name rivals, and calculate their market shares. From the selection equation, we obtain the inverse Mill's ratio (IMR), which is then used in the second step as an additional regressor. We expect a negative sign on the IMR's coefficient estimate, since the relevant markets in mergers cleared during phase 1 - for which there is a lower probability of observing rivals' market shares - are more likely to display lower concentration levels. The inclusion of the IMR in the outcome equation should correct for this type of selection bias.

\subsection{Econometric results: Basic regressions}

Table 4 uses the sample in which we have information on all market shares including rival firms. In addition to controlling for year and industry fixed-effects, we also include other

\footnotetext{
${ }^{21}$ See Andrade et al. (2001) for the drivers of merger waves and Clougherty et al. (2016) for the determinants of merging decision and deterrence.
} 
industry controls. ${ }^{22}$ Standard errors are clustered at the industry level. ${ }^{23}$ Column (1) estimates equation 1 pooling all observations, while columns (2), (3), and (4) report estimates in the sub-samples of worldwide, EU wide, and national markets, respectively.

The most consistent results are related to the barriers to entry variable. All estimated coefficients are positive and - with the exception of worldwide markets - significant. Barriers to entry unambiguously raise market concentration. The strongest marginal effects are estimated for national markets. If the EU Commission finds barriers to entry in a relevant national market, the average HHI is larger by approximately 1,400 points. Given an average $\mathrm{HHI}$ in national markets of 3,200 points, this is economically very significant. EU wide markets characterized by significant entry barriers are also significantly more concentrated. Barriers to entry, instead, do not appear to play a role in worldwide markets on average. However, this masks important heterogeneity across manufacturing and service sectors and across time (see below).

One issue with this variable concerns potential reverse causality due to the fact that the Commission might use current and past concentration in its assessment of barriers to entry. While we do not attach causal interpretation to the coefficient estimates, we think it is important to discuss this point. Affeldt et al. (2020) uses the same data as in this paper to assess the determinants of the EU Commission's decisions. They show that the probability that the Commission identifies concerns in a relevant market is positively related to indicators measuring the significant increase in concentration, dominance (the market shares of the merging parties), the existence of entry barriers, as well as the likelihood of foreclosure. The fact that entry barriers, conditional on the other structural indicators, exert a significant impact on the Commission decision can be taken as evidence that entry barriers are a dimension of the Commission decision that is, at least to some extent, independent from concentration. Moreover, Affeldt et al. (2020) also shows that the impact of barriers to entry is almost $50 \%$ larger in cases where no market share information was gathered and that the effect of entry barriers on the likelihood of competitive concerns is very stable over time, which is not the case for concentration, whose effect is decreasing. Thus, these results seem therefore to suggest that entry barriers are not chosen by the Commission based on the level of concentration.

To further address this point, we plot the distribution of our concentration measure (HHI) for product markets where the Commission found barriers to entry (see Figure 13 in Appendix A.5). The figure shows a fairly evenly spread distribution, suggesting that existing concentration does not (perfectly) determine the Commission's assessment of the existence of barriers to entry. ${ }^{24}$

Concerning the other factors, as expected, stricter merger enforcement is significantly nega-

\footnotetext{
${ }^{22}$ Industry controls are expressed as yearly changes and include: total assets; net sales/revenues; R\&D expenses; number of employees; profit margin; productivity. Tangibles refers to tangible intensity, expressed in $\%$ of VA.

${ }^{23}$ Clustering the standard errors at the merger level leads to similar results.

${ }^{24} \mathrm{As}$ an example, in its merger assessment of two airline carriers Case No COMP/M.3280 - AIR $F R A N C E / K L M$, the Commission delineated 60 product markets. While all markets were characterized by barriers to entry, the level of concentration (HHI) ranged from 25 to 10,000, with an average value of 4,159 and standard deviation of 2,944.
} 
tively correlated with concentration, however only in national markets. Moreover, also in this case, we show that there is considerable additional heterogeneity. Past merger activity appears to be positively correlated with concentration. Yet, again, there is some heterogeneity across market classes. Moreover, as mentioned above, this variable serves a dual role insofar as it also controls for the increased number of observations when there are more mergers. While the industry ratio of intangible investment to value added is positively correlated to concentration, this effect is significant only in worldwide markets.

Table 4: Estimation results - HHI, by geographic market definition

\begin{tabular}{|c|c|c|c|c|}
\hline & All & Worldwide & EU wide & National \\
\hline & (1) & $(2)$ & $(3)$ & $(4)$ \\
\hline \multirow[t]{2}{*}{ Barriers to entry at market level $\%$} & 1288.1 & 706.1 & 1166.9 & 1445.6 \\
\hline & {$[157.2]^{* * *}$} & {$[423.2]$} & {$[110.4]^{* * *}$} & {$[250.8]^{* * *}$} \\
\hline \multirow[t]{2}{*}{ Avg. ind. enforcement $R t-1$ and $t-2 \%$} & -7.11 & -0.69 & 0.57 & -9.36 \\
\hline & {$[3.32]^{* *}$} & {$[5.87]$} & {$[1.40]$} & {$[2.98]^{* * *}$} \\
\hline \multirow[t]{2}{*}{ Total ind. notifications in prev. 12 mos. } & 11.5 & 55.8 & 4.29 & 10.4 \\
\hline & {$[6.30]^{*}$} & {$[22.7]^{* *}$} & {$[7.71]$} & {$[6.49]$} \\
\hline \multirow[t]{2}{*}{ Intangibles to $V A \%$} & 4.67 & 100.7 & 3.48 & -2.17 \\
\hline & {$[18.9]$} & {$[49.2]^{*}$} & {$[16.3]$} & {$[33.7]$} \\
\hline Year FE & Yes & Yes & Yes & Yes \\
\hline Ind. FE & Yes & Yes & Yes & Yes \\
\hline Ind. controls \& Tangibles & Yes & Yes & Yes & Yes \\
\hline Clustered SE & Industry level & Industry level & Industry level & Industry level \\
\hline Observations & 9,346 & 1,198 & 2,435 & 5,713 \\
\hline $\mathrm{R} 2$ - adjusted & 0.32 & 0.40 & 0.21 & 0.31 \\
\hline
\end{tabular}

Notes: Sample All includes Year FE and Industry FE interacted with geographic market definition. Industry controls are expressed as yearly changes and include total assets; net sales/revenues; RD expenses; number of employees; profit margin; productivity. Tangibles refers to tangible intensity, expressed in \% of VA.

Standard errors clustered at the industry group level in parentheses: ${ }^{*} p<0.1,{ }^{* *} p<0.05,{ }^{* * *} p<0.01$.

Table 5 presents our results using the Heckman two-step regressions instead of a simple OLS. The sample size more than doubles when we also include markets where we only have information on merging firms to estimate the first stage. As expected, the inverse Mill's ratio is negative and significant pointing to selectivity problems when we analyze the selected sample of observations for which we observe market shares for the merging parties and competitors. Markets where mergers are cleared in phase 1 - our main excluded restriction - are significantly less likely to be included in our final sample and display significantly lower concentration levels. Controlling for selection bias allows us to check the robustness of our results with respect to at least one of the selectivity issues. Several of our findings from above carry over. Barriers to entry continue to have a positive correlation with concentration. However, this is no longer true for worldwide markets, where barriers to entry even display a negative and significant correlation with concentration. We will qualify this last result below when looking at heterogeneity across broad sector activity. Stricter past merger enforcement is still (and even more) significantly negatively related to concentration in the pooled sample as well 
as across all three sub-samples. Past merger activity and intangibles instead do not seem to show robust correlations to concentration when accounting for selection.

Table 5: Estimation results - HHI, by geographic market definition

\begin{tabular}{|c|c|c|c|c|}
\hline & All & Worldwide & EU wide & National \\
\hline & (1) & $(2)$ & $(3)$ & $(4)$ \\
\hline \multicolumn{5}{|l|}{ Post-merger HHI (low) } \\
\hline \multirow[t]{2}{*}{ Barriers to entry at market level \% } & 542.8 & -878.5 & 496.1 & 779.1 \\
\hline & {$[115.8]^{* * *}$} & {$[436.5]^{* *}$} & {$[236.1]^{* *}$} & {$[132.4]^{* * *}$} \\
\hline \multirow[t]{2}{*}{ Avg. ind. enforcement $R$ t-1 and $t$ - $2 \%$} & -13.1 & -25.3 & -6.67 & -14.1 \\
\hline & {$[1.75]^{* * *}$} & {$[8.50]^{* * *}$} & {$[3.81]^{*}$} & {$[1.98]^{* * *}$} \\
\hline \multirow{2}{*}{ Total ind. notifications in prev. 12 mos. } & 4.19 & 109.2 & -7.32 & 1.65 \\
\hline & {$[7.28]$} & {$[37.5]^{* * *}$} & {$[12.8]$} & {$[9.51]$} \\
\hline \multirow[t]{2}{*}{ Intangibles to $V A \%$} & -21.0 & 129.3 & -2.50 & -19.9 \\
\hline & {$[18.1]$} & {$[82.8]$} & {$[34.5]$} & {$[23.9]$} \\
\hline \multicolumn{5}{|l|}{ /mills } \\
\hline \multirow[t]{2}{*}{ lambda } & -2406.4 & -3628.2 & -2005.1 & -2098.7 \\
\hline & {$[301.8]^{* * *}$} & {$[811.1]^{* * *}$} & {$[612.7]^{* * *}$} & {$[345.6]^{* * *}$} \\
\hline Year FE & Yes & Yes & Yes & Yes \\
\hline Ind. FE & Yes & Yes & Yes & Yes \\
\hline Ind. controls \& Tangibles & Yes & Yes & Yes & Yes \\
\hline Clustered SE & Industry level & Industry level & Industry level & Industry level \\
\hline Observations & 21,109 & 2,313 & 5,220 & 13,576 \\
\hline
\end{tabular}

Notes: Sample All includes Year FE and Industry FE interacted with geographic market definition. Industry controls are expressed as yearly changes and include total assets; net sales/revenues; RD expenses; number of employees; profit margin; productivity. Tangibles refers to tangible intensity, expressed in $\%$ of VA.

Standard errors clustered at the industry group level in parentheses: ${ }^{*} p<0.1,{ }^{* *} p<0.05,{ }^{* * *} p<0.01$.

Summarizing our results so far, we obtain consistent results for barriers to entry and past merger enforcement. While selectivity bias is present, our main results - that barriers to entry are positively related and strict past merger enforcement is negatively related to concentration - hold up when we control for this bias. Our results on past merger activity and intangibles are more ambiguous. However, we show below that looking at even finer grained sub-samples allows us to draw more robust conclusions.

\subsection{Heterogeneity in activity and time}

In what follows, we analyze two important dimensions of heterogeneity: heterogeneity across sectoral activity (manufacturing versus services) as well as heterogeneity across time (the decade before 2004 and the decade after 2004). Sectoral heterogeneity is obviously important since technological developments differ across activities and explanations of "good" concentration evolution hinge on them (e.g. intangibility; "winner takes all" or "most" technologies (e.g. Crouzet and Eberly, 2019; Bajgar et al., 2020)). The time dimension is important since increasing concentration levels are alleged to be a rather recent phenomenon with some authors dating the beginning of increasing concentration to around the start of the new millennium 
(see e.g. Autor et al. (2020) or Gutiérrez and Philippon (2018)). Moreover, substantial changes have been introduced in European Merger control after 2004, which might affect our results (Duso et al., 2013).

Table 6 looks at heterogeneity across time. Barriers to entry are consistently and robustly positively correlated with concentration. Not only does this correlation exist before and after 2004, it is observed in all sub-samples with one exception - worldwide markets after 2004, where the coefficient is positive yet insignificant. Strict past merger enforcement is negatively correlated to concentration, however most significant coefficients are observed before 2004. Again, we do not obtain consistent results across sub-samples when analyzing the effect of past merger activity. Coefficient estimates are sometimes positive and sometimes negative, yet mostly they are not significantly different from zero. This might reflect the dual nature of use of including past merger activity, first controlling for selection bias due to observing more markets if the industry is characterized by more mergers and, second, controlling for merger wave effects on concentration. The majority of coefficient estimates for intangibles are positive but they also switch signs in some sub-samples.

Table 6: Estimation results - HHI, all geographic market definitions

\begin{tabular}{|c|c|c|c|c|c|c|c|c|}
\hline & \multicolumn{2}{|c|}{ All } & \multicolumn{2}{|c|}{ Worldwide } & \multicolumn{2}{|c|}{ EU wide } & \multicolumn{2}{|c|}{ National } \\
\hline & (1) & (2) & (3) & (4) & (5) & (6) & (7) & (8) \\
\hline & $1995-2004$ & $2005-2014$ & $1995-2004$ & $2005-2014$ & $1995-2004$ & $2005-2014$ & $1995-2004$ & $2005-2014$ \\
\hline Barriers to entry at market level \% & {$[77.4]^{* * *}$} & {$[228.1]^{* * *}$} & {$[280.2]^{* * *}$} & {$[290.5]$} & {$[83.4]^{* * *}$} & {$[161.0]^{* * *}$} & {$[95.0]^{* * *}$} & {$[369.1]^{* * *}$} \\
\hline \multirow[t]{2}{*}{ Avg. ind. enforcement $R$ t-1 and $t-2 \%$} & -11.6 & -5.06 & -17.8 & -6.68 & -11.2 & 4.14 & -11.3 & -5.54 \\
\hline & {$[0.89]^{* * *}$} & {$[2.53]^{*}$} & {$[9.75]$} & [7.31] & {$[1.17]^{* * *}$} & [2.62] & {$[1.05]^{* * *}$} & {$[2.99]^{*}$} \\
\hline Total ind. notifications in prev. $12 \mathrm{mos}$. & -28.5 & 40.6 & 17.3 & 45.1 & -14.8 & 0.96 & -38.0 & 58.8 \\
\hline \multirow[t]{2}{*}{ Intangibles to VA\% } & 131.6 & -36.0 & 297.5 & 126.1 & 276.7 & 3.47 & 96.6 & -73.2 \\
\hline & {$[48.0]^{* * *}$} & [24.5] & {$[138.7]^{*}$} & {$[54.9]^{* *}$} & {$[43.7]^{* * *}$} & {$[17.8]$} & {$[59.2]$} & {$[39.7]^{*}$} \\
\hline Year FE & Yes & Yes & Yes & Yes & Yes & Yes & Yes & Yes \\
\hline Ind. $\mathrm{FE}$ & Yes & Yes & Yes & Yes & Yes & Yes & Yes & Yes \\
\hline Ind. controls \& Tangibles & Yes & Yes & Yes & Yes & Yes & Yes & Yes & Yes \\
\hline Clustered SE & Industry level & Industry level & Industry level & Industry level & Industry level & Industry level & Industry level & Industry level \\
\hline
\end{tabular}

Notes: Sample All includes Year FE and Industry FE interacted with geographic market definition. Industry controls are expressed as yearly changes and include total assets; net sales/revenues; RD expenses; number of employees; profit margin; productivity. Tangibles refers to tangible intensity, expressed in \% of VA.

Standard errors clustered at the industry group level in parentheses: ${ }^{*} p<0.1, * * p<0.05, * * * p<0.01$.

Table 7 looks at the heterogeneity of our findings differentiating between manufacturing and services sectors. Again, barriers to entry are unambiguously negatively related to concentration with the possible exception of worldwide services markets where the coefficient estimate is not significantly different from zero. Stricter past merger enforcement, again, appears to be negatively correlated with concentration, particularly so in national manufacturing markets. Past merger activity is positively related to concentration, particularly so in wider than national markets (EU wide and worldwide), as well as in services markets. Intangibility again gives inconclusive results, with concentration being positively correlated with the share of intangible investments in EU and worldwide markets but negatively linked to concentration in EU wide manufacturing markets.

Finally, Table 8 displays results on the most flexible specifications accounting for both 
Table 7: Estimation results - HHI, by geographic market definition

\begin{tabular}{|c|c|c|c|c|}
\hline & All & Worldwide & EU wide & National \\
\hline & (1) & (2) & (3) & (4) \\
\hline \multirow[t]{2}{*}{ Barriers to entry at market level $\% \times$ Manufacturing } & 1280.9 & 1416.6 & 1220.9 & 1309.2 \\
\hline & {$[97.6]^{* * *}$} & {$[99.8]^{* * *}$} & {$[41.8]^{* * *}$} & {$[149.4]^{* * *}$} \\
\hline \multirow[t]{2}{*}{ Barriers to entry at market level $\% \times$ Services } & 1321.7 & 272.7 & 1022.0 & 1962.4 \\
\hline & {$[554.9]^{* *}$} & {$[140.3]^{*}$} & {$[314.0]^{* * *}$} & {$[620.2]^{* * *}$} \\
\hline \multirow[t]{2}{*}{ Avg. ind. enforcement $R$ t- 1 and $t$ - $2 \% \times$ Manufacturing } & -6.18 & 6.95 & 1.50 & -9.85 \\
\hline & {$[4.05]$} & {$[3.42]^{*}$} & {$[0.98]$} & {$[2.94]^{* * *}$} \\
\hline \multirow[t]{2}{*}{ Avg. ind. enforcement $R t-1$ and $t-2 \% \times$ Services } & -8.89 & -3.65 & -10.5 & -7.47 \\
\hline & {$[5.30]$} & {$[8.02]$} & {$[7.16]$} & [6.28] \\
\hline \multirow[t]{2}{*}{ Total ind. notifications in prev. 12 mos. $\times$ Manufacturing } & 8.44 & 44.6 & -1.97 & 7.50 \\
\hline & {$[5.94]$} & {$[12.2]^{* * *}$} & [4.69] & [6.19] \\
\hline \multirow[t]{2}{*}{ Total ind. notifications in prev. $12 \mathrm{mos} . \times$ Services } & 30.3 & 112.4 & 116.3 & 13.0 \\
\hline & {$[25.0]$} & {$[52.6]^{*}$} & {$[44.4]^{* *}$} & [29.1] \\
\hline \multirow[t]{2}{*}{ Intangibles to $V A \% \times$ Manufacturing } & -4.17 & 100.5 & -9.10 & 4.89 \\
\hline & {$[24.7]$} & [59.2] & [18.0] & [35.0] \\
\hline \multirow[t]{2}{*}{ Intangibles to VA $\% \times$ Services } & 45.0 & 214.3 & 115.9 & 25.1 \\
\hline & {$[36.1]$} & {$[78.1]^{* *}$} & {$[52.1]^{* *}$} & {$[46.6]$} \\
\hline Year FE & Yes & Yes & Yes & Yes \\
\hline Ind. FE & Yes & Yes & Yes & Yes \\
\hline Ind. controls \& Tangibles & Yes & Yes & Yes & Yes \\
\hline Clustered SE & Industry level & Industry level & Industry level & Industry level \\
\hline Observations & 9,346 & 1,198 & 2,435 & 5,713 \\
\hline $\mathrm{R} 2$ - adjusted & 0.32 & 0.41 & 0.21 & 0.32 \\
\hline
\end{tabular}

Notes: Sample All includes Year FE and Industry FE interacted with geographic market definition. Industry controls are expressed as yearly changes and include total assets; net sales/revenues; RD expenses; number of employees; profit margin; productivity. Tangibles refers to tangible intensity, expressed in $\%$ of VA.

Standard errors clustered at the industry group level in parentheses: ${ }^{*} p<0.1,{ }^{* *} p<0.05,{ }^{* * *} p<0.01$. 
types of heterogeneity (in addition to the three types of geographical dimensions) - across time and sector of activity - simultaneously. Barriers to entry are unambiguously positively correlated with concentration - all coefficients are positive and 13 of the 14 coefficients are significant. This is overwhelming evidence of the importance of barriers to entry to explain concentration dynamics irrespective of time periods, sectors of activity, and geographical market dimension. Barriers to entry are also economically the by far most important correlates with concentration. Strict merger enforcement continues to show predominantly negative correlation with concentration; however, it appears that this correlation was actually larger and more significant in the earlier decade. Past merger activity remains ambiguous, with larger positive correlation with concentration in the latter sample decade. Intangibility of investments displays consistent positive correlation with concentration for wider than national - EU wide and worldwide - services markets. In contrast, it is negatively correlated with concentration in national markets. This underscores the importance of controlling for the large heterogeneity present across markets as well as controlling for geographical market extension.

Table 8: Estimation results - HHI, all geographic market definitions

\begin{tabular}{|c|c|c|c|c|c|c|c|c|}
\hline & \multicolumn{2}{|c|}{ All } & \multicolumn{2}{|c|}{ Worldwide } & \multicolumn{2}{|c|}{ EU wide } & \multicolumn{2}{|c|}{ National } \\
\hline & (1) & (2) & (3) & (4) & (5) & (6) & (7) & (8) \\
\hline & $1995-2004$ & 2005-2014 & $1995-2004$ & 2005-2014 & $1995-2004$ & 2005-2014 & $1995-2004$ & 2005-2014 \\
\hline Barriers to entry at market level $\% \times$ Manufacturing & 1443.5 & 1148.3 & 2100.9 & 972.4 & 1238.9 & 1161.4 & 1469.6 & 1205.9 \\
\hline \multirow[t]{2}{*}{ Barriers to entry at market level $\% \times$ Services } & 1416.0 & 1283.5 & 3332.5 & 193.7 & 3149.1 & 963.2 & 1337.3 & 2598.6 \\
\hline & {$[365.6]^{* * *}$} & {$[656.9]^{*}$} & {$[626.0]^{* * *}$} & {$[104.8]^{*}$} & {$[1348.2]^{* *}$} & {$[298.3]^{* * *}$} & {$[418.7]^{* * *}$} & {$[781.4]^{* * *}$} \\
\hline Avg. ind. enforcement $R t-1$ and $t-2 \% \times$ Manufacturing & -11.6 & -4.18 & -17.4 & 0.18 & -10.2 & 7.01 & -11.8 & -6.30 \\
\hline Avg. ind. enforcement $R t-1$ and $t-2 \% \times$ Services & {$[3.69]^{* * *}$} & [6.72] & [85.9] & [9.11] & {$[35.3]$} & [8.71] & {$\left[\left.2.79\right|^{* * *}\right.$} & [5.41] \\
\hline \multirow[t]{2}{*}{ Total ind. notifications in prev. 12 mos. $\times$ Manufacturing } & -35.5 & 44.8 & 15.7 & 39.3 & -15.3 & -1.33 & -48.0 & 70.6 \\
\hline & {$[7.27]^{* * *}$} & {$[18.0]^{* *}$} & {$[27.8]$} & [33.2] & {$[5.30]^{* *}$} & {$[10.8]$} & {$[9.35]^{* * *}$} & {$[9.66]^{* * *}$} \\
\hline \multirow[t]{2}{*}{ Total ind. notifications in prev. 12 mos. $\times$ Services } & 20.6 & 30.6 & 57.1 & 210.1 & -2.33 & 114.0 & 15.6 & 24.8 \\
\hline & [38.8] & [30.1] & [43.2] & {$[71.4]^{* *}$} & [77.5] & {$[60.8]^{*}$} & {$[40.6]$} & {$[39.3]$} \\
\hline \multirow{2}{*}{ Intangibles to VA $\% \times$ Manufacturing } & 177.9 & -46.6 & 391.0 & 82.3 & 241.0 & -9.31 & 174.8 & -59.7 \\
\hline & {$[79.8]^{* *}$} & {$[23.8]^{*}$} & {$[147.2]^{* *}$} & [67.9] & {$[105.4]^{* *}$} & {$[20.3]$} & [128.0] & {$[31.7]^{*}$} \\
\hline Ind. controls \& Tangibles & Yes & Yes & Yes & Yes & Yes & Yes & Yes & Yes \\
\hline Clustered SE & Industry level & Industry level & Industry level & Industry level & Industry level & Industry level & Industry level & Industry level \\
\hline Observations & 3,583 & 5,763 & 220 & 978 & 1,034 & 1,401 & 2,329 & 3,384 \\
\hline R2 - adjusted & 0.23 & 0.38 & 0.29 & 0.43 & 0.14 & 0.28 & 0.24 & 0.40 \\
\hline
\end{tabular}

Notes: Sample All includes Year FE and Industry FE interacted with geographic market definition. Industry controls are expressed as yearly changes and include total assets; net sales/revenues; RD expenses; number of employees; profit margin; productivity. Tangibles refers to tangible intensity, expressed in \% of VA.

Standard errors clustered at the industry group level in parentheses: ${ }^{*} p<0.1,{ }^{* *} p<0.05, * * * p<0.01$.

\section{Conclusion}

This paper makes a number of improvements over the extant literature on increasing concentration and its determinants. By using industry classifications and firm balance sheet data to calculate market shares and concentration, it fails to accurately and appropriately measure concentration. For the first time, this paper utilizes a dataset containing correct market shares by relying on exact antitrust market definitions from more than 20,000 mar- 
kets affected by more than 2,000 mergers over the $1995 \mathrm{~s}-2014$ period. The market definitions were made by the EU Commission in the course of legal merger control proceedings. This allows us to use precise measures on the geographic as well as product market boundaries and, therefore, market shares. We complement this dataset with information on merger control enforcement and on other industry wide measures.

Our basic research questions are whether concentration is rising in EU markets and, if so, what are potential drivers/correlates explaining these dynamics? We focus on within-industry variation and analyze the four main channels: barriers to entry, merger control enforcement, merger activity, and intangible investment. While improving on the measurement of market shares and concentration compared to existing studies, our data suffer from at least two types of selection bias. We are confined to observing market shares only in markets characterized by mergers and, even in these cases, to situations where the EU Commission scrutinizes the merger in depth and reports market shares for the merging parties and their rivals. We account for both types of selectivity issues by including a variable controlling for past merger activity and estimating Heckman two-step regressions. Results are consistent despite selectivity.

Our main results are summarized as follows. First and descriptively, our measures of concentration are much larger than what the literature so far documents. We obtain average concentration measures (HHI) of around 3,000 while most of the literature comes up with numbers being easily smaller by a factor of ten. We report increasing concentration on average in well defined antitrust markets, however this average tendency masks substantial heterogeneity across markets. The extent of the geographic market as well the broad sector of activity play a crucial role in this assessment. While national markets and markets in manufacturing only show slight increases in concentration or even decreased concentration (e.g., in worldwide manufacturing) over the 20-year period from 1995 to 2014, services markets, particularly when they are EU or worldwide, display large increases in concentration.

Second, we turn to regression analysis to exploit the large amount of heterogeneity observed across markets. Results on the most flexible specifications accounting for three dimensions of heterogeneity (geographical dimension, time periods, and sector of activity) simultaneously are as follows. Barriers to entry unambiguously increase concentration - all coefficients are positive and 13 of the 14 coefficients are significant. This is overwhelming evidence that barriers to entry are positively related to concentration irrespective of time periods, sectors of activity, and geographical market dimension. Barriers to entry are also economically the byfar most important correlate with concentration. Past merger enforcement is predominantly negatively related to concentration; however, it appears that the effect of enforcement on concentration was actually more stringent in the earlier decade (1995-2004) than in the latter sample decade (2005-2014). The relation between past merger activity and concentration is rather ambiguous, with larger positive estimates in the latter sample decade. Intangibility of investments displays consistent positive correlation with concentration for wider - EU wide and worldwide - than national services markets. In contrast, it is negatively related to concentration in national markets. This underscores the importance of controlling for the 
large heterogeneity present in cross market analysis as well as controlling for geographical market extension.

This brings us back to the question of whether (increasing) concentration is due to "good" (efficiency) or "bad" (increase of market power) reasons. We find that it depends, since both types of patterns seem to be present in different markets. A verdict of good concentration can be derived from the results related to intangible investment, which point to scalability effects. Intangible assets, however, are only positively related to concentration in broad markets (EU wide and worldwide) as well as in services. In national markets and in most manufacturing markets, we do not observe these positive patterns. In contrast, barriers to entry matter in all markets and they are economically the most important correlate to concentration. Moreover, past merger activity and - more consistently so - strict past merger enforcement are systematically related to concentration. These results might hint at the fact that concentration, in many markets, is mostly driven by anti-competitive, market-power enhancing forces.

Which policy responses would our results warrant? Our results on barriers to entry and past merger enforcement call for strict merger control enforcement. Even the EU Commission - possibly the strictest and most efficient antitrust institution - may consider becoming even more restrictive or at least maintain its current tough stance on antitrust. Of course, other institutions and, in particular, national antitrust agencies - including, possibly, the US FTC or DoJ - would need to catch up. However, tearing down barriers to entry is not the sole task of antitrust authorities. Other policy areas such as regulation, institutions setting norms and standards as well as international cooperation agreements must contribute. Notwithstanding this conclusion, there are circumstances in certain antitrust markets - e.g. high intangible asset industries in geographically wide services markets - where increasing concentration may indeed be likely related to increasing efficiency. It is the task of antitrust authorities to strike the delicate balance between these forces. 


\section{References}

Affeldt, Pauline, Tomaso Duso, and Florian Szücs, "EU Merger Control Database: 1990-2014," DIW Data Documentation, 2018, 95.

_ , _ , and _ , "25 Years of European Merger Control," CEPR Discussion Papers, 2020, DP 14548 .

Ahern, Kenneth R and Jarrad Harford, "The Importance of Industry Links in Merger Waves," The Journal of Finance, 2014, 69 (2), 527-576.

Ali, Ashiq, Sandy Klasa, and Eric Yeung, "The Limitations of Industry Concentration Measures Constructed with Compustat Data: Implications for Finance Research," The Review of Financial Studies, 2008, 22 (10), 3839-3871.

Andrade, Gregor, Mark Mitchell, and Erik Stafford, "New Evidence and Perspectives on Mergers," Journal of Economic Perspectives, 2001, 15 (2), 103-120.

Autor, David, David Dorn, Lawrence F. Katz, Christina Patterson, and John Van Reenen, "The Fall of the Labor Share and the Rise of Superstar Firms," Quarterly Journal of Economics, Forthcoming, 2020.

Bajgar, Matej, Chiara Criscuolo, and Jonathan Timmis, "Supersize Me: Intangibles and Industry Concentration," 2020.

_ , Giuseppe Berlingieri, Sara Calligaris, Chiara Criscuolo, and Jonathan Timmis, "Industry Concentration in Europe and North America," 2019.

Bernheim, B Douglas, "Strategic Deterrence of Sequential Entry into an Industry," The Rand Journal of Economics, 1984, 15 (1), 1-11.

Berry, Steven, Martin Gaynor, and Fiona Scott Morton, "Do Increasing Markups Matter? Lessons from Empirical Industrial Organization," Journal of Economic Perspectives, 2019, 33 (3), 44-68.

Bresnahan, Timothy F., "Empirical Studies of Industries with Market Power," in R. Schmalensee and R. D. Willig, eds., Handbook of Industrial Organization, Vol. 2, Elsevier Science Publishers, 1989, chapter 17, pp. 1011-1057.

Bresnahan, Timothy F and Richard Schmalensee, "The Empirical Renaissance in Industrial Economics: An Overview," The Journal of Industrial Economics, 1987, 35 (4), $371-378$

Calligaris, Sara, Chiara Criscuolo, and Luca Marcolin, "Mark-Ups in the Digital Era," OECD Science, Technology and Industry Working Papers, 2018, No. 2018/10.

Calvino, Flavio, Chiara Criscuolo, Luca Marcolin, and Mariagrazia Squicciarini, "A Taxonomy of Digital Intensive Sectors," OECD Science, Technology and Industry Working Papers, 2018, No. 2018/14. 
Clougherty, Joseph A, Tomaso Duso, Miyu Lee, and Jo Seldeslachts, "Effective European Antitrust: Does EC Merger Policy Generate Deterrence?," Economic Inquiry, 2016, 54 (4), 1884-1903.

Crouzet, Nicolas and Janice C Eberly, "Understanding Weak Capital Investment: The Role of Market Concentration and Intangibles," Technical Report, National Bureau of Economic Research 2019.

Duso, Tomaso, Klaus Gugler, and Burcin B Yurtoglu, "How Effective is European Merger Control?," European Economic Review, 2011, 55 (7), 980-1006.

_ , _, and Florian Szücs, "An Empirical Assessment of the 2004 EU Merger Policy Reform," The Economic Journal, 2013, 123 (572), F596-F619.

Farrell, Joseph and Carl Shapiro, "Antitrust Evaluation of Horizontal Mergers: An Economic Alternative to Market Definition," The BE Journal of Theoretical Economics, 2010, $10(1)$.

Fletcher, Amelia and Bruce Lyons, "Geographic Market Definition in European Commission Merger Control," Study Commissioned by DG Competition January 2016.

Foerster, Andrew, Andreas Hornstein, Pierre-Daniel Sarte, and Mark W Watson, "Aggregate Implications of Changing Sectoral Trends," Technical Report, National Bureau of Economic Research 2019.

Gilbert, Richard and Xavier Vives, "Entry Deterrence and the Free Rider Problem," The Review of Economic Studies, 1986, 53 (1), 71-83.

Grullon, Gustavo, Yelena Larkin, and Roni Michaely, "Are US Industries Becoming More Concentrated?," Review of Finance, 2019, 23 (4), 697-743.

Gutiérrez, Germán and Thomas Philippon, "How EU Markets became More Competitive than US Markets: A Study of Institutional Drift," Technical Report, National Bureau of Economic Research 2018.

Hausman, Jerry, Gregory Leonard, and J Douglas Zona, "Competitive Analysis with Differenciated Products," Annales d'Economie et de Statistique, 1994, pp. 159-180.

Hsieh, Chang-Tai and Esteban Rossi-Hansberg, "The Industrial Revolution in Services," Technical Report, National Bureau of Economic Research 2019.

Loecker, Jan De and Jan Eeckhout, "Global Market Power," Technical Report, National Bureau of Economic Research 2018.

_ , , , and Gabriel Unger, "The Rise of Market Power and the Macroeconomic Implications," The Quarterly Journal of Economics, 2020, 135 (2), 561-644.

Philippon, Thomas, The Great Reversal: How America Gave Up on Free Markets, Harvard University Press, 2019. 
Rossi-Hansberg, Esteban, Pierre-Daniel Sarte, and Nicholas Trachter, "Diverging Trends in National and Local Concentration," NBER Macroeconomics Annual, Forthcoming., 2020.

Shapiro, Carl, "Antitrust in a Time of Populism," International Journal of Industrial Organization, 2018, 61, 714-748.

Stehrer, Robert, Alexandra Bykova, Kirsten Jäger, Oliver Reiter, and Monika Schwarzhappel, "Industry-level Growth and Productivity Data with Special Focus on Intangible Assets: Report on methodologies and data construction for the EU KLEMS Release 2019," The Vienna Institute for International Economic Studies, 2019.

Sutton, John, Sunk Costs and Market Structure: Price Competition, Advertising, and the Evolution of Concentration, MIT press, 1991.

Tambe, Prasanna, Lorin Hitt, Daniel Rock, and Erik Brynjolfsson, "Digital Capital and Superstar Firms," NBER Working Paper Series, 2020, 28285.

Waldman, Michael, "Noncooperative Entry Deterrence, Uncertainty, and the Free Rider Problem," The Review of Economic Studies, 1987, 54 (2), 301-310.

Werden, Gregory J, "A Robust Test for Consumer Welfare Enhancing Mergers Among Sellers of Differentiated Products," The Journal of Industrial Economics, 1996, 44 (4), 409-413.

- and Luke M Froeb, "Don't Panic: A Guide to Claims of Increasing Concentration," Antitrust Magazine, forthcoming, 2018.

Wright, Joshua D., "Market Concentration - Note by Joshua D. Wright. Hearing on Market Concentration," OECD Paper DAF/COMP/WD(2018)69 June 2018. 


\section{A. Appendix}

\section{A.1. EU KLEMS industry classification}

Table 9: EU KLEMS - codes and description

\begin{tabular}{|c|c|}
\hline Code & Description \\
\hline A & A Agriculture, forestry and fishing \\
\hline $\mathrm{B}$ & B Mining and quarrying \\
\hline $\mathrm{C}$ & C TOTAL MANUFACTURING \\
\hline $\mathrm{C} 10 \_\mathrm{C} 12$ & C10-12 Food products, beverages and tobacco \\
\hline $\mathrm{C} 13_{-}^{-} \mathrm{C} 15$ & C13-15 Textiles, wearing apparel, leather and related products \\
\hline $\mathrm{C} 16_{-}^{-} \mathrm{C} 18$ & C16-18 Wood and paper products; printing and reproduction of recorded media \\
\hline $\mathrm{C} 19^{-}$ & C19 Coke and refined petroleum products \\
\hline $\mathrm{C} 20$ & C20 Chemicals and chemical products \\
\hline $\mathrm{C} 21$ & C21 Basic pharmaceutical products and pharmaceutical preparations \\
\hline $\mathrm{C} 22 \_\mathrm{C} 23$ & C22-23 Rubber and plastics products, and other non-metallic mineral products \\
\hline $\mathrm{C} 24_{-}^{-} \mathrm{C} 25$ & C24-25 Basic metals and fabricated metal products, except machinery and equipment \\
\hline $\mathrm{C} 26^{-}$ & C26 Computer, electronic and optical products \\
\hline $\mathrm{C} 27$ & C27 Electrical equipment \\
\hline $\mathrm{C} 28$ & C28 Machinery and equipment n.e.c. \\
\hline C29_C30 & C29-30 Transport equipment \\
\hline C31_C33 & C31-33 Other manufacturing; repair and installation of machinery and equipment \\
\hline $\mathrm{D}^{-}$ & D Electricity, gas, steam and air conditioning supply \\
\hline $\mathrm{E}$ & E Water supply; sewerage; waste management and remediation activities \\
\hline $\mathrm{F}$ & F Construction \\
\hline G & G WHOLESALE AND RETAIL TRADE; REPAIR OF MOTOR VEHICLES AND MOTORCYCLES \\
\hline G45 & G45 Wholesale and retail trade and repair of motor vehicles and motorcycles \\
\hline G46 & G46 Wholesale trade, except of motor vehicles and motorcycles \\
\hline G47 & G47 Retail trade, except of motor vehicles and motorcycles \\
\hline $\mathrm{H}$ & H TRANSPORTATION AND STORAGE \\
\hline H49 & H49 Land transport and transport via pipelines \\
\hline $\mathrm{H} 50$ & H50 Water transport \\
\hline $\mathrm{H} 51$ & H51 Air transport \\
\hline $\mathrm{H} 52$ & H52 Warehousing and support activities for transportation \\
\hline H53 & H53 Postal and courier activities \\
\hline I & I Accommodation and food service activities \\
\hline $\mathrm{J}$ & J INFORMATION AND COMMUNICATION \\
\hline J58_J60 & J58-60 Publishing, audio-visual and broadcasting activities \\
\hline $\mathrm{J} 61^{-}$ & J61 Telecommunications \\
\hline J62_J63 & J62-63 IT and other information services \\
\hline $\mathrm{K}$ & K Financial and insurance activities \\
\hline $\mathrm{L}$ & L Real estate activities \\
\hline M_N & M-N Professional, scientific, technical, administrative and support service activities \\
\hline $\mathrm{O}^{-}$ & O Public administration and defence; compulsory social security \\
\hline $\mathrm{P}$ & P Education \\
\hline $\mathrm{Q}$ & Q Health and social work \\
\hline $\mathrm{R}$ & $\mathrm{R}$ Arts, entertainment and recreation \\
\hline $\mathrm{S}$ & S Other service activities \\
\hline $\mathrm{T}$ & $\mathrm{T}$ Activities of households as employers; undifferentiated goods- and services-producing activities of households for own use \\
\hline $\mathrm{U}$ & U Activities of extraterritorial organizations and bodies \\
\hline
\end{tabular}




\section{A.2. Worldscope industry controls}

Table 10: Definition of Industry Controls

\begin{tabular}{l|l}
\hline Variable & Definition \\
\hline Total assets (USD) & $\begin{array}{l}\text { Represent the sum of total current assets, long term receivables, invest- } \\
\text { ment in unconsolidated subsidiaries, other investments, net property } \\
\text { plant and equipment and other assets. Converted to U.S. dollars using } \\
\text { the fiscal year end exchange rate. }\end{array}$ \\
\hline Net sales or revenues (USD) & $\begin{array}{l}\text { Represent gross sales and other operating revenue less discounts, re- } \\
\text { turns and allowances. Converted to U.S. dollars using the fiscal year } \\
\text { end exchange rate. }\end{array}$ \\
\hline Research and development & $\begin{array}{l}\text { Represents all direct and indirect costs related to the creation and de- } \\
\text { velopment of new processes, techniques, applications and products with } \\
\text { commercial possibilities. }\end{array}$ \\
\hline Employees & $\begin{array}{l}\text { Number of both full and part time employees of the company. Excludes } \\
\text { seasonal and emergency employees. }\end{array}$ \\
\hline Profitability & Calculated as net income divided by total assets. \\
\hline \hline
\end{tabular}

Definitions from Worldscope Datatype Definitions Guide. 


\section{A.3. Evolution of explanatory variables}

Figure 6: Evolution of Entry Barriers
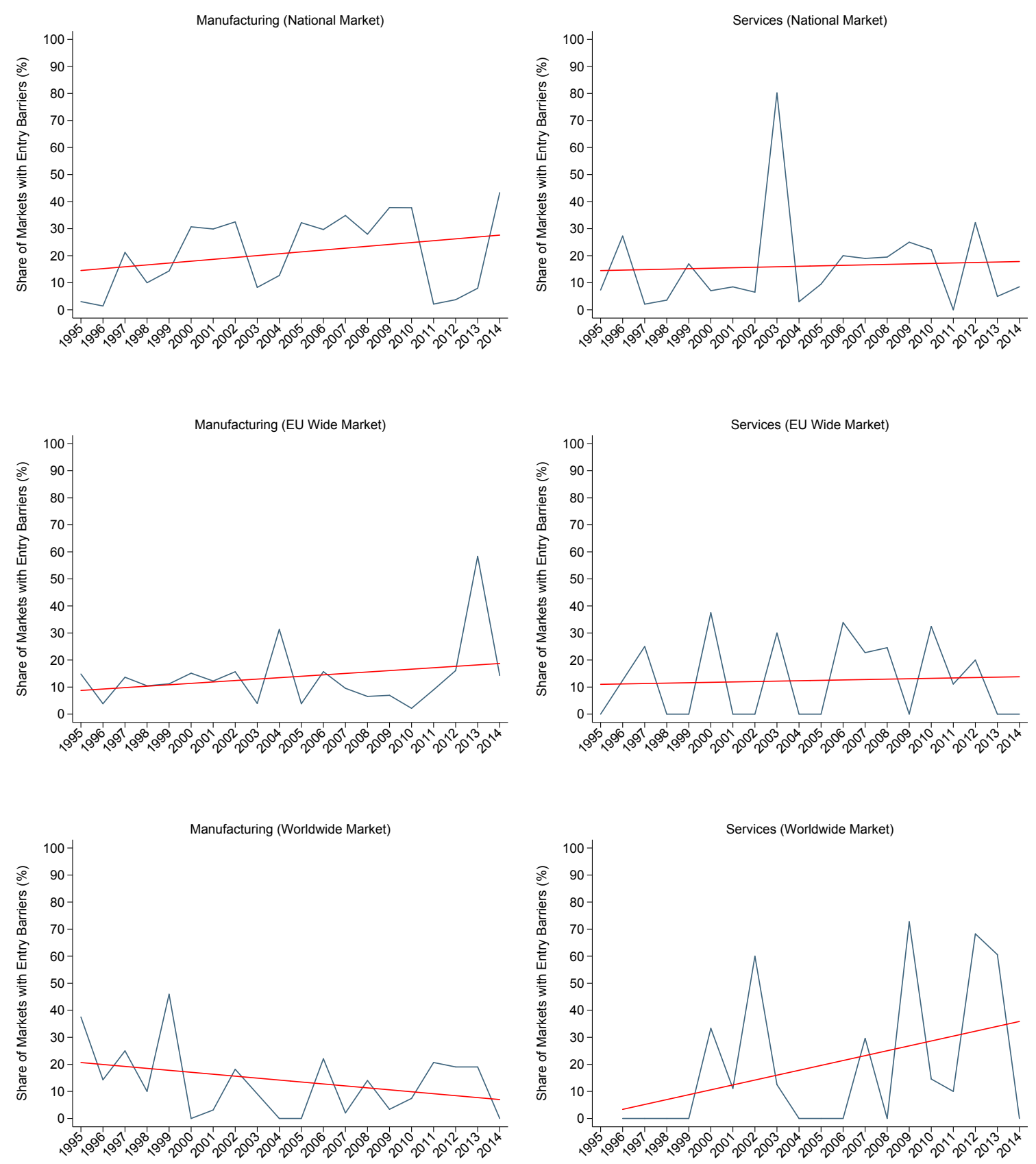

Source: Our elaboration on EU merger data. 
Figure 7: Evolution of Past Industry Enforcement Ratios
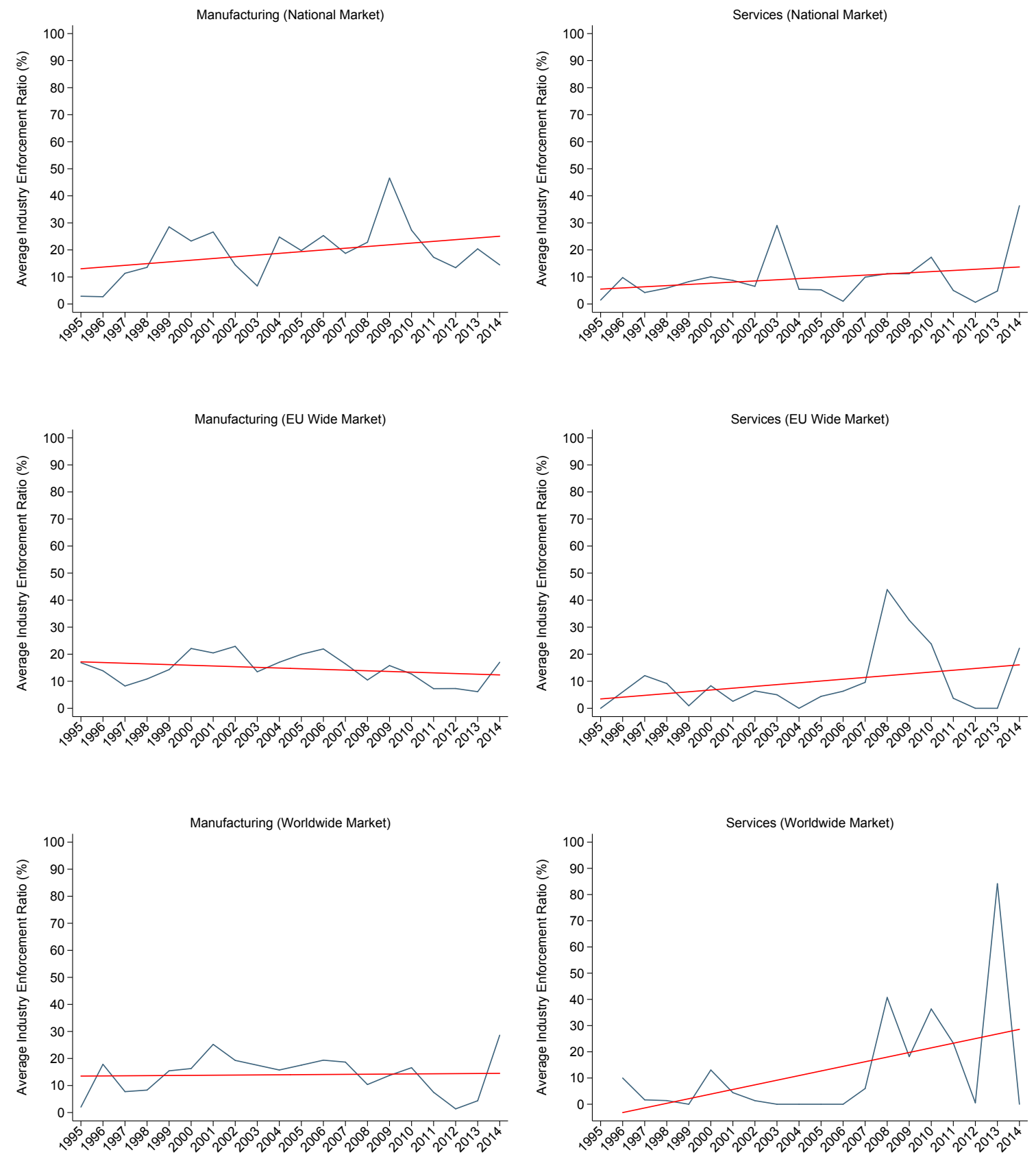

Source: Our elaboration on EU merger data. 
Figure 8: Evolution of Industry Merger Notifications (t-1)
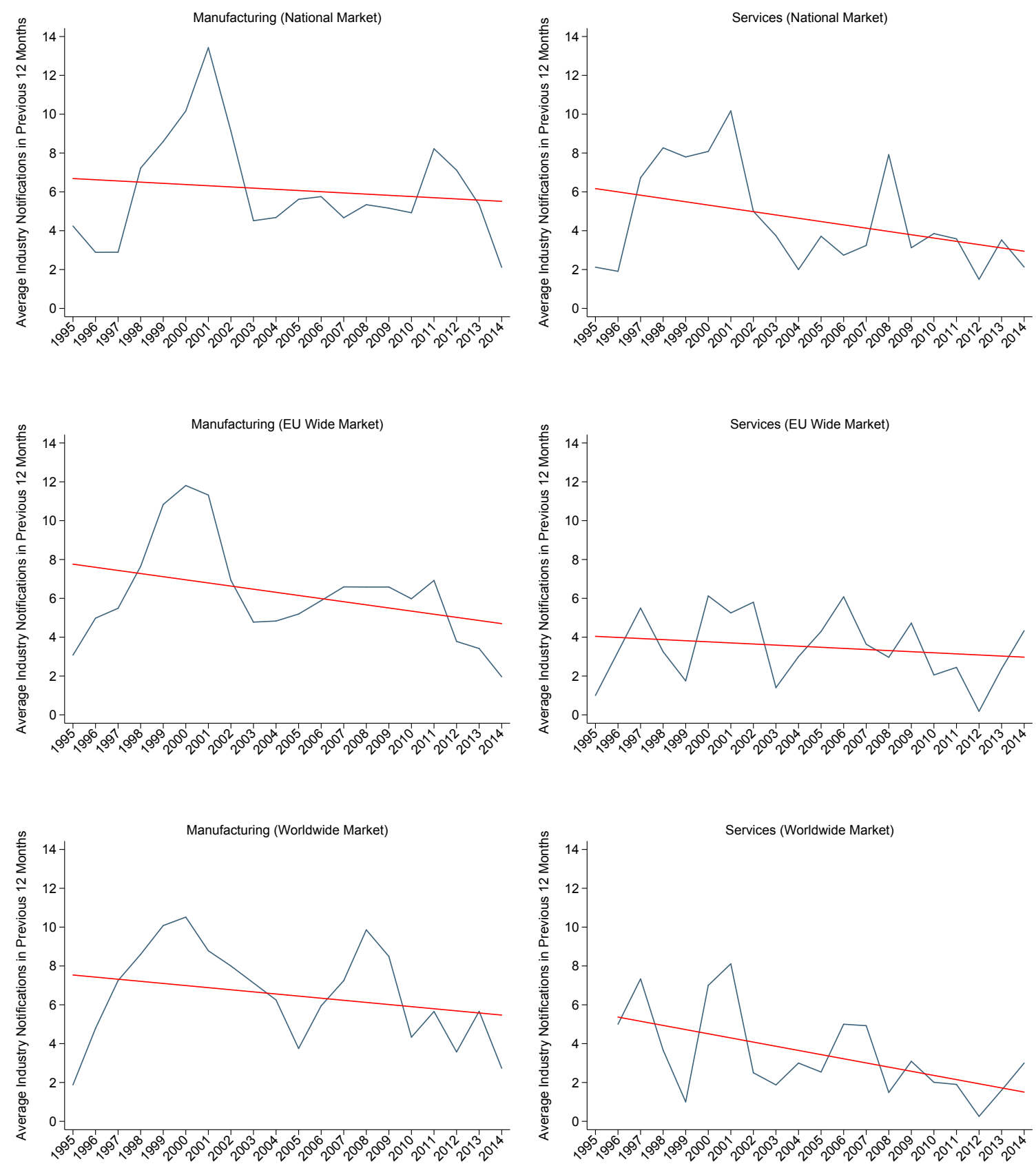

Source: Our elaboration on EU merger data. 
Figure 9: Evolution of Intangible asset intensity
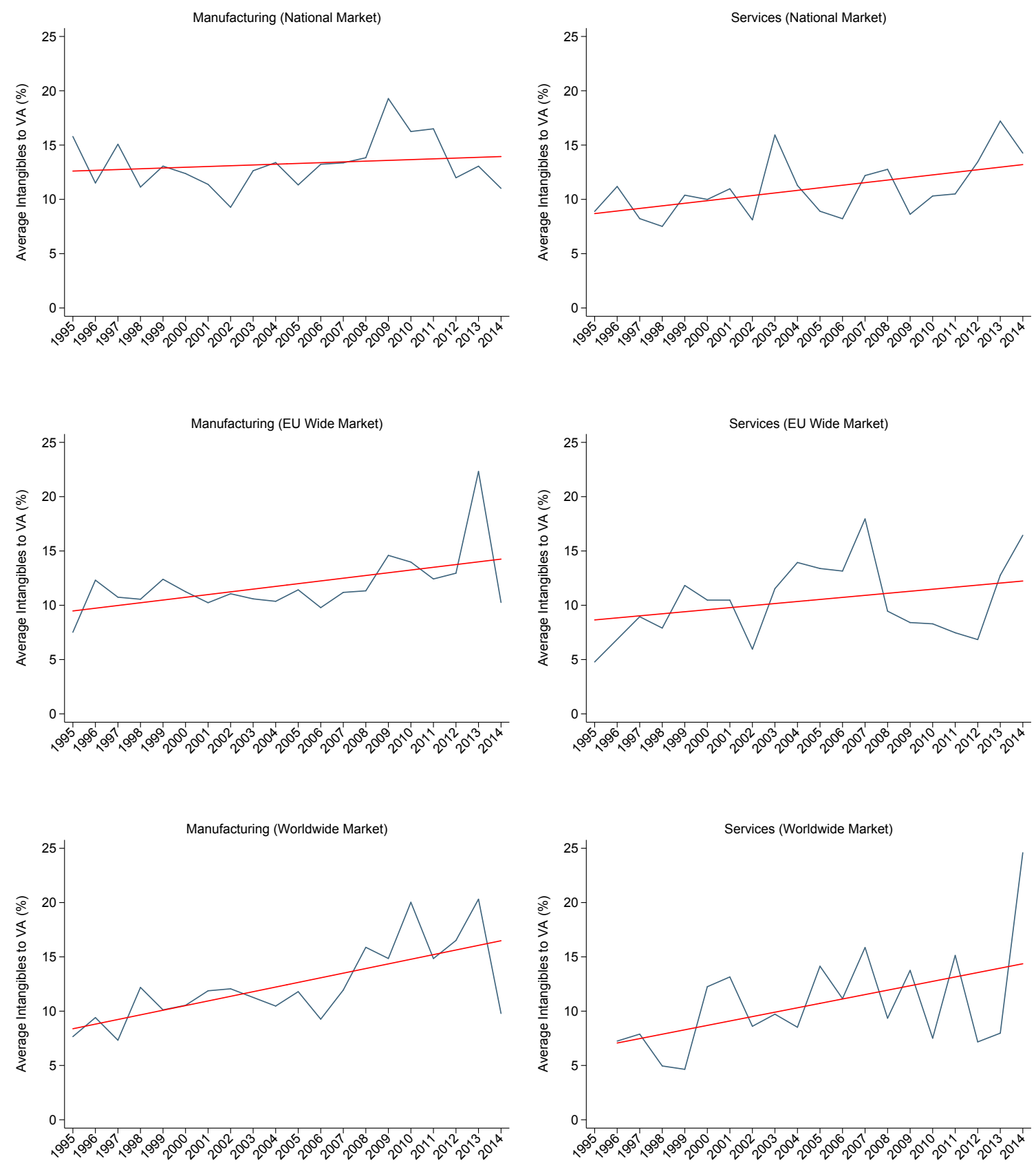

Source: Our elaboration on EU merger data and EU KLEMS data. 


\section{A.4. Possible caveats}

Figure 10 pictures the occurrence of our antitrust markets (number of observations) across EU KLEMS industries and time. Nearly all industries are covered by our database, although not in every year. In some industries, especially manufacturing, we have several observations for each industry-year combination. There are, however, also exceptions with few(er) antitrust markets observed in industries such as "O: Public administration and defense," "R: Arts, entertainment and recreation," and "A: agriculture, forestry and fishing." Yet, the picture is an indication that the sample selectivity stemming from only observing market share data when there are mergers might not be too large.

Another way of looking at the potential selection in our data is analyzing the distribution of the number of firms across industries from our EU merger database and compare it to the distribution of the number of firms from a different database, which is supposed to represent the entire world economy. To do this exercise, we use data from Worldscope to get a representation of the relative size of each industry in terms of number of firms. While Worldscope only focuses on large enterprises, thus missing the lower tale of the firm distribution, it is also one of the few databases with world-coverage. Figure 11 reports the two distributions. ${ }^{25}$ While some industries appear to be over-sampled (e.g. C10-12, C20, G46, J61) and others under-sampled (e.g. B, C15, C26, F, L, Q, R, S) in our EU merger database, the two distributions seem to have quite a similar shape.

Finally, Figure 12 reports the percentage of (Worldscope) aggregated industry sales that is covered by the (Worldscope) firms entailed in our EU merger database. While for several industries, the matched firms - including merging firms and rivals - account for over $50 \%$ of the total industry sales (most notably in manufacturing) in other industries (such as A, E, F, H49, I, R U) they account for less than $20 \%$.

\footnotetext{
${ }^{25}$ Notice that, given the non-panel nature of our EU merger data we use the entire sample period to compute the distribution of firms across industries. For Worldscope, instead, we compute the share of firms in each industry for each year and then report the average.
} 
Figure 10: Number of observations, by EU KLEMS code and notification date
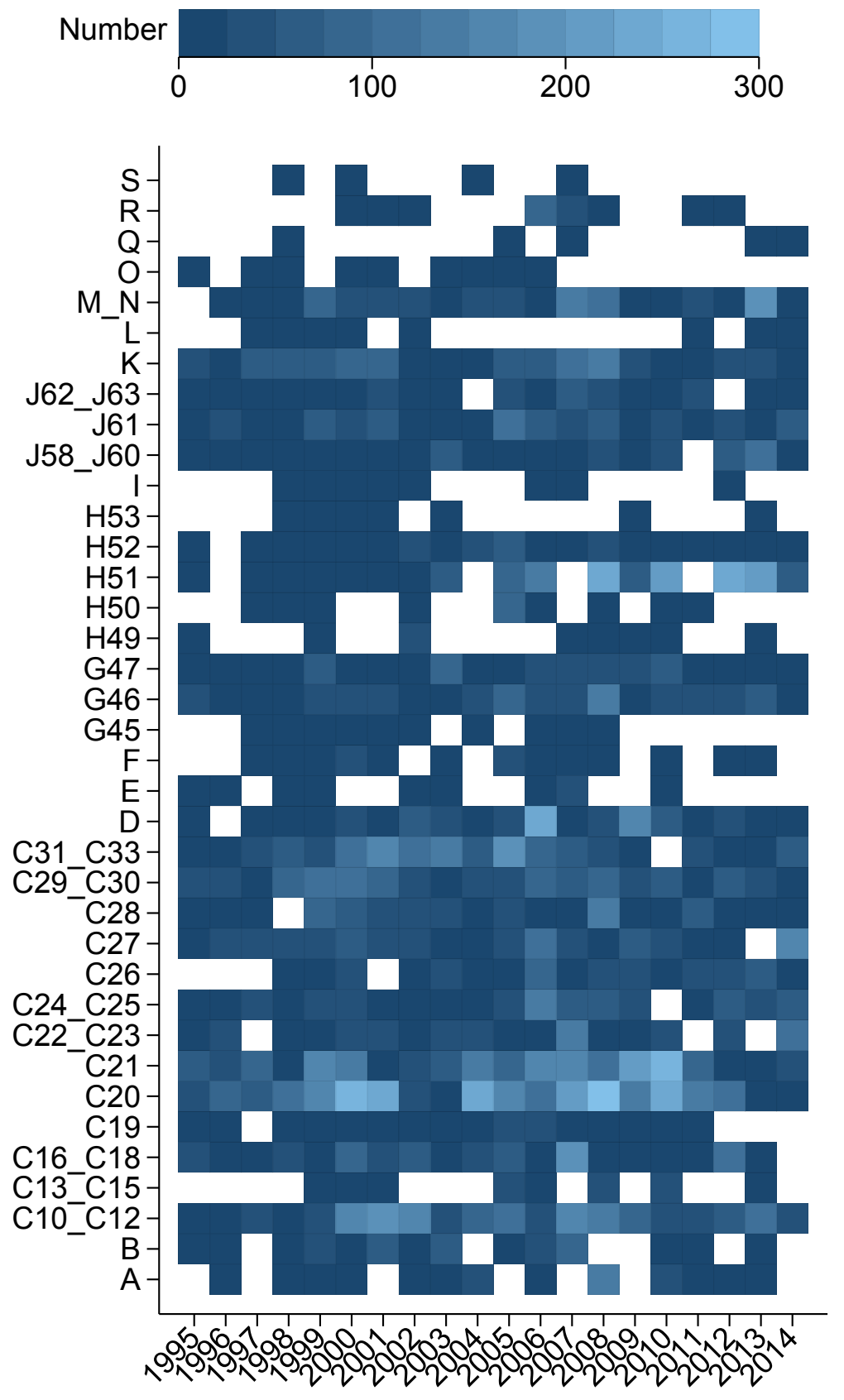

Source: Our elaboration on EU merger data. Based on sample including 21,109 markets. 
Figure 11: Distribution of the number of firms across industries: EU merger database vs. Worldscope

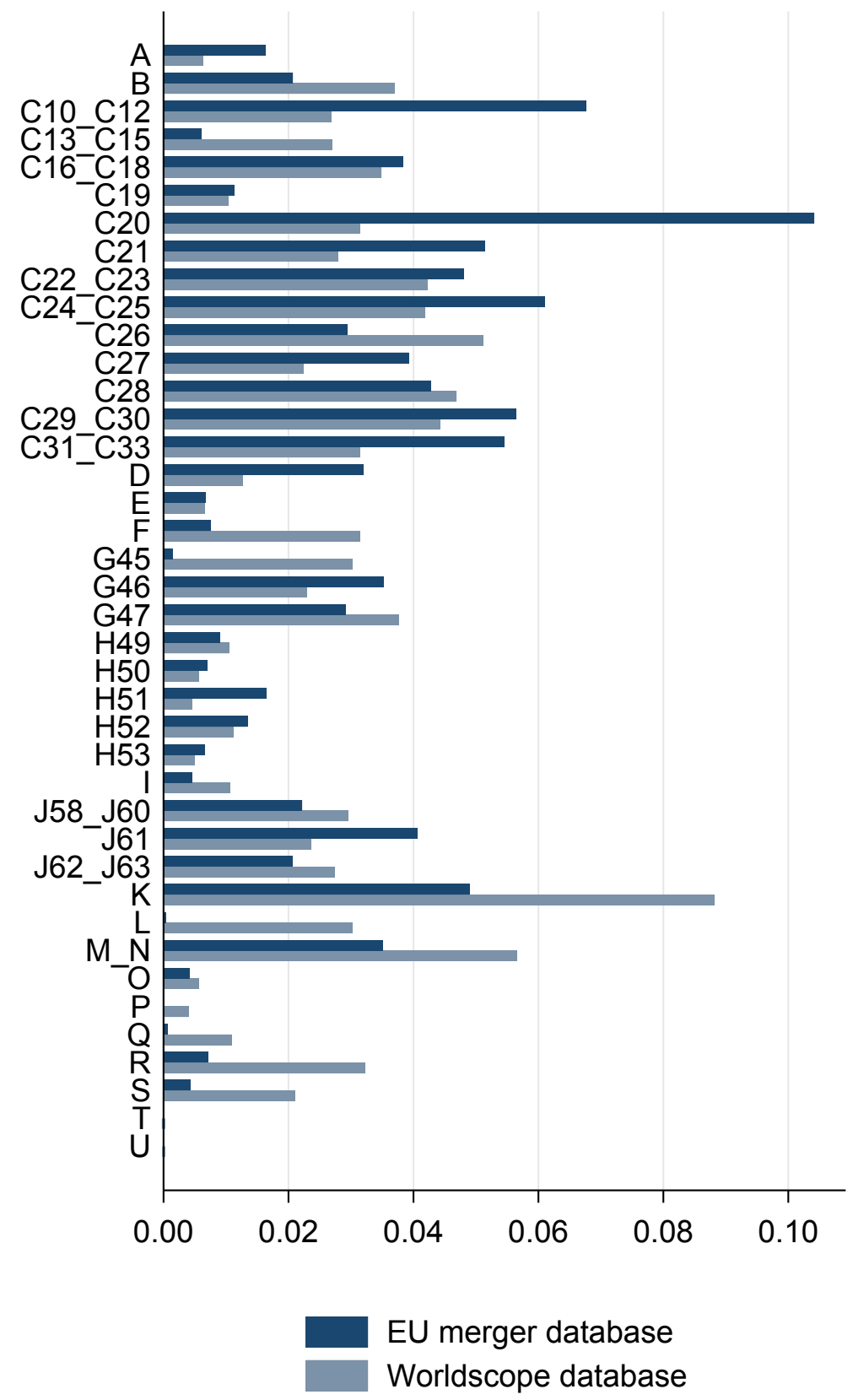


Figure 12: Fraction of industry sales in Worldscope covered by firms included in the EU merger database, by EU KLEMS industry

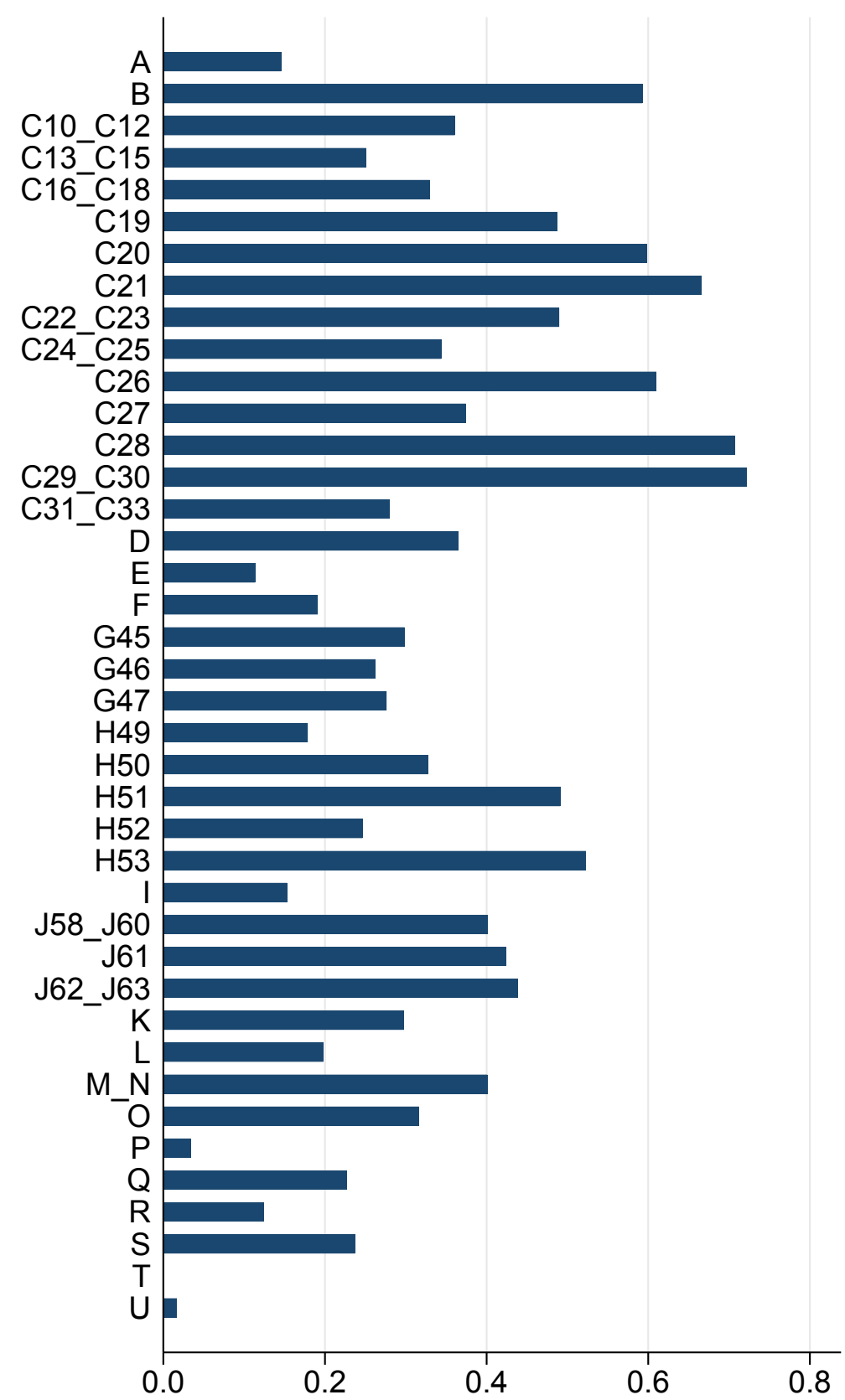




\section{A.5. Potential identification issues}

Figure 13: Distribution of concentration (HHI) in the years 1995-2014 for markets with identified barriers to entry

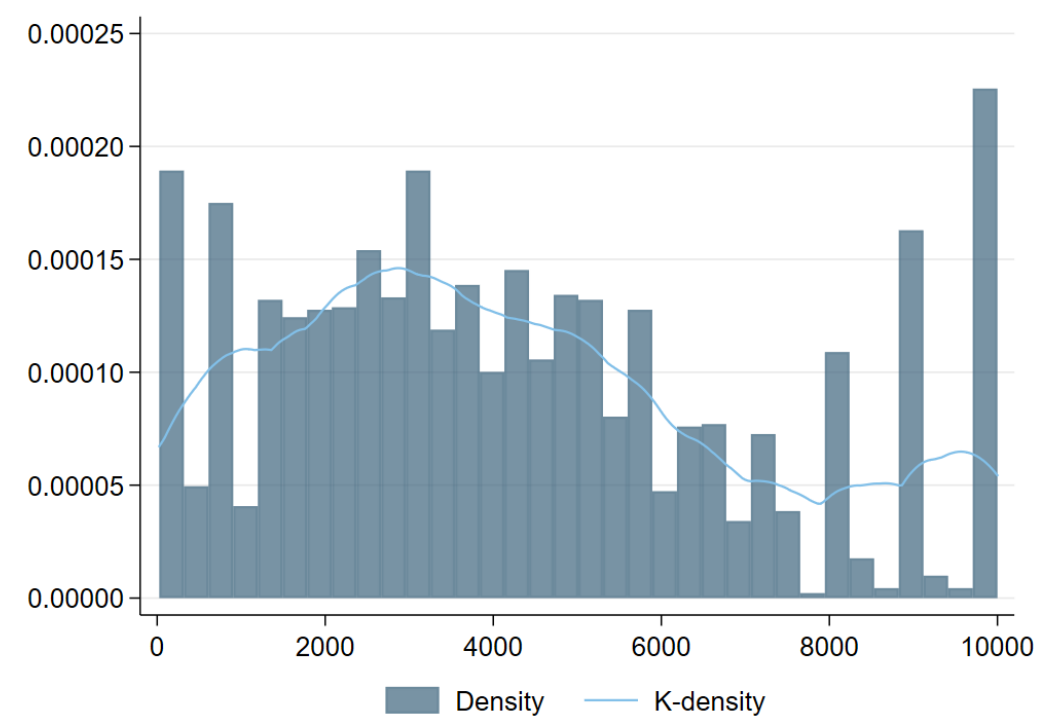

Source: Our elaboration on EU merger data. Based on sample including 21,109 markets. 